\title{
OPEN Annual phytoplankton dynamics in coastal waters from Fildes Bay, Western Antarctic Peninsula
}

\author{
Nicole Trefault ${ }^{1,5 \bowtie}$, Rodrigo De la Iglesia ${ }^{2}{ }^{2,5}$, Mario Moreno-Pino ${ }^{1}$, \\ Adriana Lopes dos Santos $\mathbb{1}^{3}$, Catherine Gérikas Ribeiro $\mathbb{1}^{1}$, Génesis Parada-Pozo ${ }^{1}$, \\ Antonia Cristi ${ }^{1}$, Dominique Marie ${ }^{4}$ \& Daniel Vaulot $\mathbb{1}^{3,4}$
}

Year-round reports of phytoplankton dynamics in the West Antarctic Peninsula are rare and mainly limited to microscopy and/or pigment-based studies. We analyzed the phytoplankton community from coastal waters of Fildes Bay in the West Antarctic Peninsula between January 2014 and 2015 using metabarcoding of the nuclear and plastidial 18/16S rRNA gene from both size-fractionated and flow cytometry sorted samples. Overall 14 classes of photosynthetic eukaryotes were present in our samples with the following dominating: Bacillariophyta (diatoms), Pelagophyceae and Dictyochophyceae for division Ochrophyta, Mamiellophyceae and Pyramimonadophyceae for division Chlorophyta, Haptophyta and Cryptophyta. Each metabarcoding approach yielded a different image of the phytoplankton community with for example Prymnesiophyceae more prevalent in plastidial metabarcodes and Mamiellophyceae in nuclear ones. Diatoms were dominant in the larger size fractions and during summer, while Prymnesiophyceae and Cryptophyceae were dominant in colder seasons. Pelagophyceae were particularly abundant towards the end of autumn (May). In addition of Micromonas polaris and Micromonas sp. clade B3, both previously reported in Arctic waters, we detected a new Micromonas 18 S rRNA sequence signature, close to, but clearly distinct from $M$. polaris, which potentially represents a new clade specific of the Antarctic. These results highlight the need for complementary strategies as well as the importance of year-round monitoring for a comprehensive description of phytoplankton communities in Antarctic coastal waters.

Phytoplankton represents the main energy input to the marine ecosystem in Antarctica, providing fixed carbon to marine and terrestrial systems, being the primary food source, and therefore the base of the entire Antarctic food $\mathrm{web}^{1,2}$. Summer phytoplankton blooms in nutrient rich coastal waters are critical to fuel the Antarctic marine ecosystem and to maintain energy fluxes during the long winter. Each year, the temperature increase and the melting of ice during the Austral spring induce a succession of phytoplankton communities. Understanding this succession is crucial, since it has profound implications at planetary scales, from the architecture and efficiency of the trophic webs, to the carbon sedimentation to deep waters and the global biogeochemical cycles ${ }^{3}$. Monitoring natural phytoplankton populations is challenging, especially in high latitude environments such as Antarctica given logistical field difficulties. Long time series such as the Rothera Time Series (RaTS) and the Palmer Long-Term Ecological Research (PAL-LTER) program help understanding of the year-round Antarctic phytoplankton dynamics.

The Western Antarctic Peninsula (WAP) is one of the fastest warming areas on Earth ${ }^{4}$ and is characterized by strong spatial and temporal variability ${ }^{5}$. Previous studies have shown regional differences between the northern and southern areas of the WAP, mainly related to mixed layer depth and phytoplankton productivity ${ }^{6}$, as well as inter-decadal variability of phytoplankton biomass along the coast of the WAP, with essential role of local-scale forcing on phytoplankton dynamics ${ }^{7}$. Differences between WAP eastern and western coastal areas have also been observed, mostly dominated by benthic and pelagic diatoms, respectively ${ }^{8}$. A two year sampling study in Admiralty Bay (King George Island, WAP) reported that spring-summer biomass maxima were dominated by

\footnotetext{
${ }^{1}$ GEMA Center for Genomics, Ecology and Environment, Faculty of Sciences, Universidad Mayor, 8580745 Santiago, Chile. ${ }^{2}$ Department of Molecular Genetics and Microbiology, Pontificia Universidad Católica de Chile, Alameda 340, 8331150 Santiago, Chile. ${ }^{3}$ Asian School of the Environment, Nanyang Technological University, 50 Nanyang Avenue, Singapore 639798, Singapore. ${ }^{4}$ Ecology of Marine Plankton Team, UMR7144, CNRS, Sorbonne Université, Station Biologique, 29680 Roscoff, France. ${ }^{5}$ These authors contributed equally: Nicole Trefault and Rodrigo De la Iglesia. ${ }^{\circledR}$ email: nicole.trefault@umayor.cl; vaulot@gmail.com
} 
pico-phytoplankton and nano-sized flagellates, followed in abundance by diatoms and dinoflagellates ${ }^{9}$. In Ryder Bay (Adelaide Island), high temperatures were reported to be correlated with an increase in nano-sized cryptophytes, whereas the haptophyte Phaeocystis antarctica increased in relation to high irradiance and low salinity ${ }^{10}$. P. antarctica, which is replaced by Phaeocystis pouchetii in the Arctic ocean ${ }^{11}$, is widely present in the WAP ${ }^{10,12}$ as well as in other Antarctic regions ${ }^{13,14}$. In Fildes Bay (King George Island), phytoplankton shows a rapid increase in biomass and cell abundance as a consequence of short vertical mixing events in the water column, with a strong dominance of nano-phytoplankton, represented by Thalassiosira and Phaeocystis ${ }^{12}$. Large diatoms, Phaeocystis, and mixotrophic/phagotrophic dinoflagellates, explain most spatial variability in the carbon export potential of the WAP ${ }^{15}$. More recently, metagenomic and metatranscriptomic analyses of pico- and nano- size fractions of the plankton community from Chile Bay (Greenwich Island, WAP) indicated that, while diatoms completely dominated the DNA-based analyses, alveolates, cryptophytes and haptophytes appeared besides diatoms in the RNA-based analyses, suggesting that these other phytoplankton groups may be actively growing despite a low contribution to $\mathrm{DNA}^{16}$. From the spatial point of view, variation of phytoplankton across environmental gradients in Fildes Bay, studied using flow cytometry and metabarcoding of the plastidial 16S rRNA gene, indicated that, although the community composition was mostly similar at sub-mesoscale, the abundance of specific phytoplankton groups was responsive to salinity and nutrient gradients ${ }^{17}$.

Environmental sequencing of taxonomic marker genes first by the Sanger technique and then by high throughput techniques (metabarcoding) has improved our ability to detect and identify groups that are difficult to cultivate or identify by other methodologies (e.g. microscopy). Two marker genes have been used for phytoplankton diversity studies: nuclear $18 \mathrm{~S}$ rRNA and plastidial $16 \mathrm{~S}$ RNA $^{18,19}$ yielding quite different images of the community structure ${ }^{20}$. The use of different cell collection and filtering approaches results in differences in the image of the phytoplankton community composition: besides size-fractionation by filtration, a classical approach based on cell size proposed by Sieburth et al. in $1978^{21}$, flow cytometry sorting enables to better assess the diversity of small photosynthetic eukaryotes for the pico- and nano-sized fractions ${ }^{22,23}$.

The aim of the present study was to assess changes in phytoplankton abundance, diversity and community composition occurring during the Austral year. We sampled the phytoplankton community in coastal waters from Fildes Bay (also called Maxwell Bay, South Shetland Islands, WAP) between January 2014 and 2015, and used three complementary metabarcoding approaches: size-fractionated samples with the nuclear 18S rRNA and plastidial 16S rRNA genes, and flow cytometry sorted samples with the 18S rRNA gene.

\section{Results}

Phytoplankton dynamics. We sampled phytoplankton in coastal waters of Fildes Bay, King George Island, at the eastern tip of the WAP (Fig. 1A), between January 2014 and 2015 at all seasons except winter (Table 1). Using flow cytometry, we detected three eukaryotic phytoplankton populations: pico-eukaryotes (PPE), nanoeukaryotes (PNE) and cryptophytes (CRY), while marine cyanobacteria (Prochlorococcus, Synechococcus) could not be detected in any sample. Phytoplankton abundance was higher during the summer compared to the rest of the year (Fig. 1B). In autumn, we detected low and uniform levels of the three phytoplankton populations with values between 47 and 342 cells $\mathrm{mL}^{-1}$ for CRY and PPE, respectively (Supplementary Data S1). CRY showed similar values between summer 2014 and 2015, while PPE and PNE showed an inverted pattern of abundance. PNE were, on average, three times higher than PPE in summer 2015, while it was the reverse in 2014.

Nutrients $\left(\mathrm{NO}_{3}^{-}, \mathrm{PO}_{4}^{3-}, \mathrm{SiO}_{3}^{2-}\right)$ showed maximum levels during autumn and spring, when lower phytoplankton abundance was recorded, and minimum levels during summer, when phytoplankton abundance was higher (Fig. 1C). Silica was the nutrient with the highest concentration, followed by nitrate and phosphate. Chlorophyll $a(\mathrm{Chl} a)$ concentration, a proxy of phytoplankton biomass, was below $0.4 \mathrm{mg} \mathrm{m}^{-3}$ in autumn and spring. Chl $a$ was higher in summer 2014 compared to 2015 (Fig. 1D).

Overall composition of the phytoplankton community. Phytoplankton composition was analyzed by three different metabarcoding approaches (Tables 1 and 2). Filtered samples ( 3 size fractions) were analyzed using both the nuclear $18 \mathrm{~S}$ rRNA gene, hereafter 18S-filter, and the plastidial 16S rRNA gene, hereafter 16S-filter, while during summer 2015 we were also able to obtain $18 \mathrm{~S}$ rRNA sequences from flow cytometry sorted populations (pico- and nano-phytoplankton), hereafter $18 \mathrm{~S}$-sort. The sequence data were processed with the dada2 pipeline ${ }^{24}$ that clusters reads into amplicon sequence variant (ASV). In this paper, we are focusing on the five major eukaryotic divisions that contain photosynthetic taxa: Ochrophyta (in particular diatoms), Chlorophyta (green algae), Haptophyta, Cryptophyta and Rhodophyta (mostly macroalgae). Because a large fraction of dinoflagellate species are heterotrophic, even within the same genus ${ }^{25}$, and Chrysophyceae (Ochrophyta) ASVs were assigned to heterotrophic taxa such as Paraphysomonas or Spumella or to uncultured clades that are known or hypothesized to be heterotrophic, we have excluded these groups from our analysis. Classes for which all the taxa recovered corresponded to macro-algae were also excluded: Bangiophyceae and Florideophyceae (Rhodophyta), Xanthophyceae and Phaeophyceae (Ochrophyta). The total number of ASVs corresponding to photosynthetic taxa varied from 189 for the sorted samples to 564 for the filtered samples. The average number of reads corresponding to photosynthetic taxa was around 30,000 per sample (Table 2).

An analysis performed in January 2015 over a vertical profile revealed that the water column was not stratified (Table S1) and that the composition of the phytoplankton community at the class level in each size fraction (Figure S1) was fairly uniform vertically. Therefore surface samples were considered to be representative of the whole water column. It should be noted however that some species were only found at depth in the euphotic zone samples and not in surface (Table S2).

Phytoplankton communities in WAP coastal waters were highly diverse, with 14 classes and 156 species detected in surface samples (Table S3). The major classes were Bacillariophyta (diatoms), Pelagophyceae and 
A
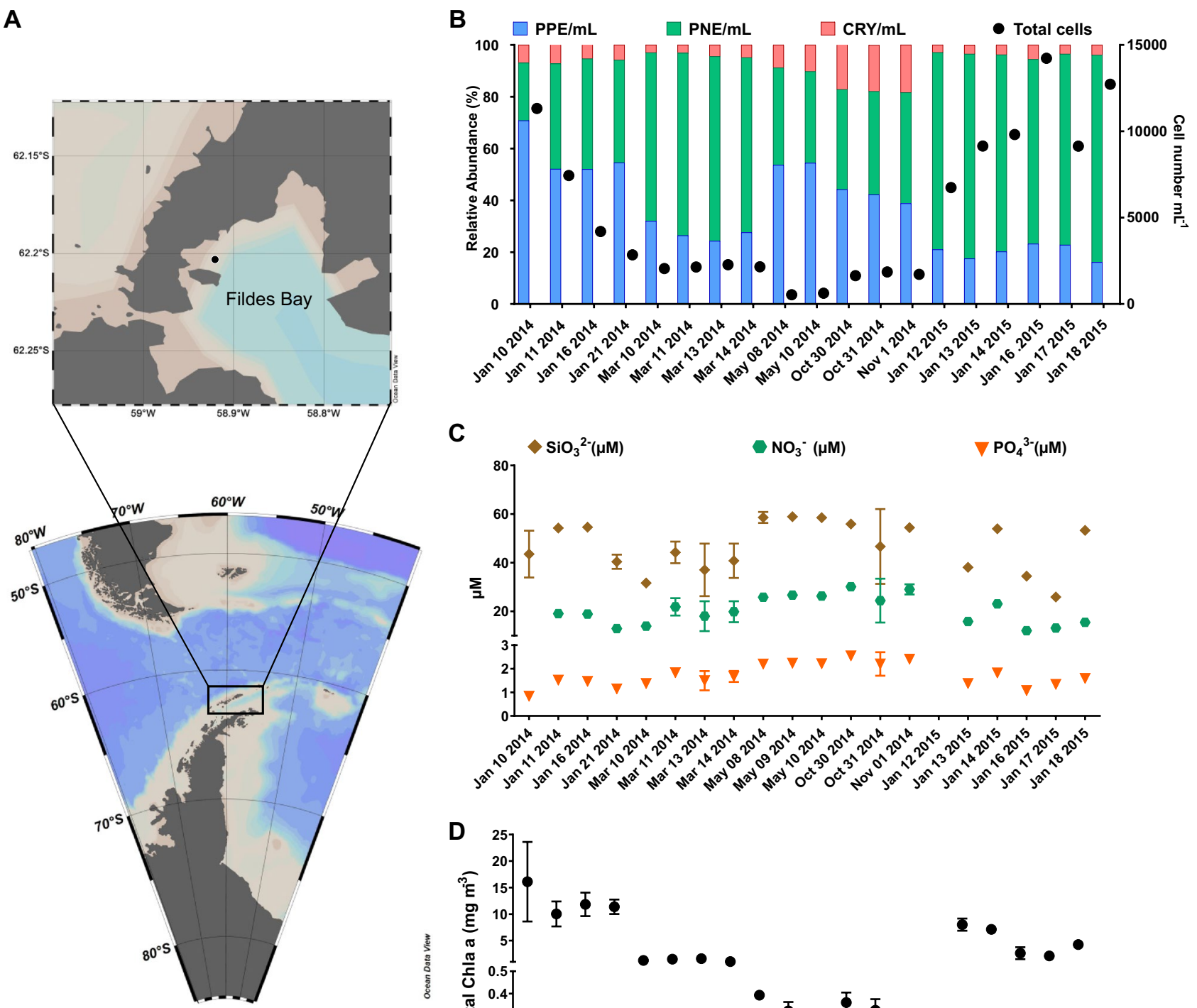

C
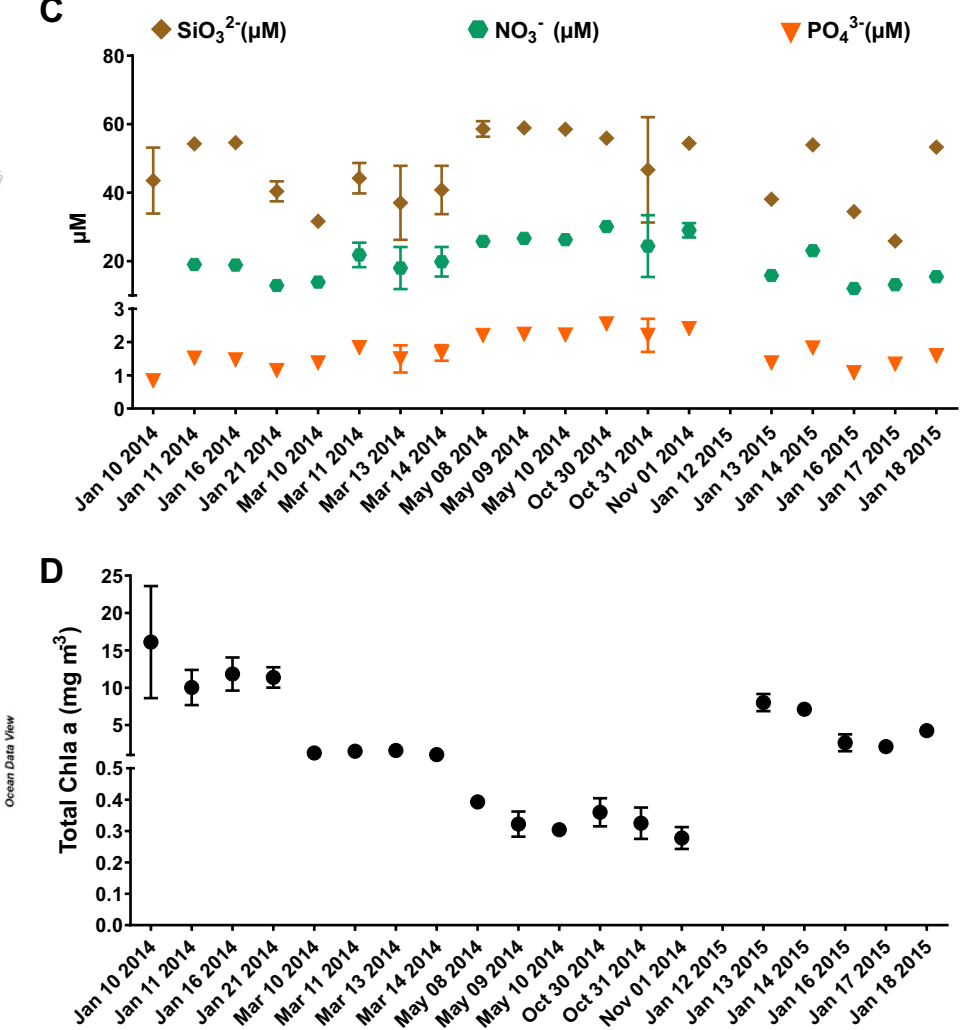

Figure 1. Location of the sampling station (Station 6) in Fildes Bay, King George Island, Western Antarctic Peninsula (WAP) and biotic and abiotic characteristics between January 2014 and January 2015. (A) Map of the Antarctica Peninsula and location of the station in Fildes Bay sampled in this study. (B) Phytoplankton abundance measured by flow cytometry. Detected populations correspond to PPE = photosynthetic picoeukaryotes, $\mathrm{PNE}=$ photosynthetic nano-eukaryotes, and CRY $=$ cryptophytes. $(\mathrm{C})$ Nutrients (silicate, $\mathrm{SiO}_{3}^{2-}$; nitrate, $\mathrm{NO}_{3}^{-}$and phosphate, $\mathrm{PO}_{4}^{3-}$ ). (D) Chlorophyll $a$ levels during the sampling period. Values correspond to biomass $<100 \mu \mathrm{m}$. For $\mathrm{B}, \mathrm{C}$, and $\mathrm{D}$, values represent mean \pm standard deviation.

Dictyochophyceae for division Ochrophyta, Mamiellophyceae and Pyramimonadophyceae for division Chlorophyta (green algae), Prymnesiophyceae (Haptophyta) and Cryptophyceae (Cryptophyta) (Figs. 2 and S2).

Among Ochrophyta, Bacillariophyta were dominating with the species Porosira glacialis, Fragilariopsis cylindrus and Chaetoceros neogracilis, and the genera Minidiscus and Thalassiosira as major taxa. The sequence of the main ASV assigned to C. neogracilis (found in both 18S-filter and 18S-sort datasets) is $100 \%$ similar to an Antarctic strain AnM0002 (Genbank EU090012) but differs by 7 positions within the V4 region of the 18S rRNA gene (98.1\% similarity) from all Arctic strains, suggesting that it is a distinct, yet undescribed, species (Figure S3). For some genera such as Thalassiosira and Minidiscus, the identification down to the species level is difficult because reference sequences are lacking for Antarctic species. The sequence of the main Minidiscus ASV (asv_016_00002 from the $18 \mathrm{~S}$-filter dataset also found in the 18S-sort dataset) is 100\% similar (Figure S4) to strain RCC4582 (Genbank MH843669) which was isolated from Fildes Bay in January 2015. RCC4582 cells are about $5 \mu \mathrm{m}$ in size and have been tentatively identified as M. chilensis (unpublished observations). This sequence (asv_016_00002) 


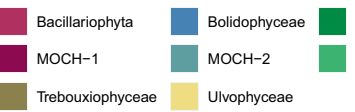

Minidiscus sp

Porosira glacialis Geminigera cryophila Pelagophyceae sp. Bathycoccus prasinos Fragilariopsis cylindrus Micromonas polaris

Thalassiosira antarctica

Thalassiosira minima

Pedinellales sp.

Thalassiosira sp.

Phaeocystis antarctica

Corethron inerme

Pyramimonas gelidicol

Micromonas clade B3

Chaetoceros neogracilis

Pseudo-nitzschia seriata

Triparma laevis clade

Pelagomonas calceolata

Parmales env $3 \mathrm{~B} \mathrm{sp}$.

$$
\text { o }
$$
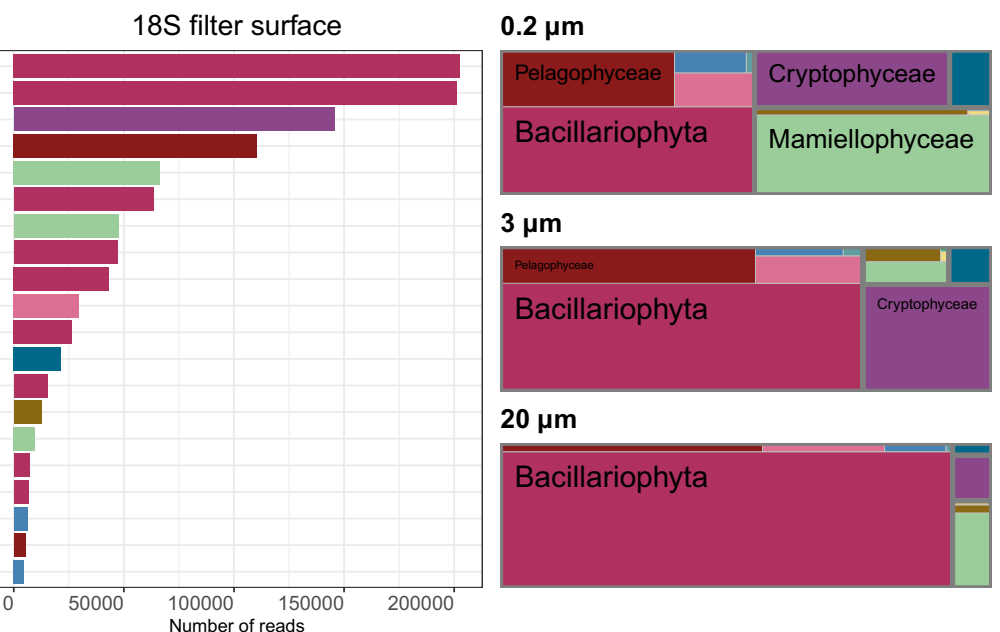

$3 \mu \mathrm{m}$

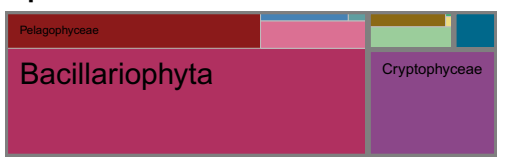

$20 \mu \mathrm{m}$

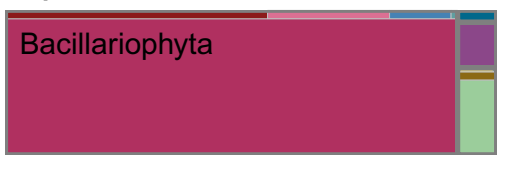

Phaeocystis antarctica Micromonas polaris Minidiscus sp.

Fragilariopsis cylindrus

Chaetoceros neogracilis

Pelagophyceae sp.

Geminigera cryophila

Pyramimonas gelidicola

Thalassiosira minima

Thalassiosira sp.

Prymnesiophyceae Clade B3 sp.

Triparma laevis clade

Bathycoccus prasinos

Micromonas clade B3

Chrysochromulina sp.

Parmales env 3B sp.

Asteroplanus karianus

Phaeocystis sp.

Pelagomonas calceolata

Porosira glacialis$$
\left\{\begin{array}{l}
1 \\
-1
\end{array}\right.
$$

$18 S$ sort surface

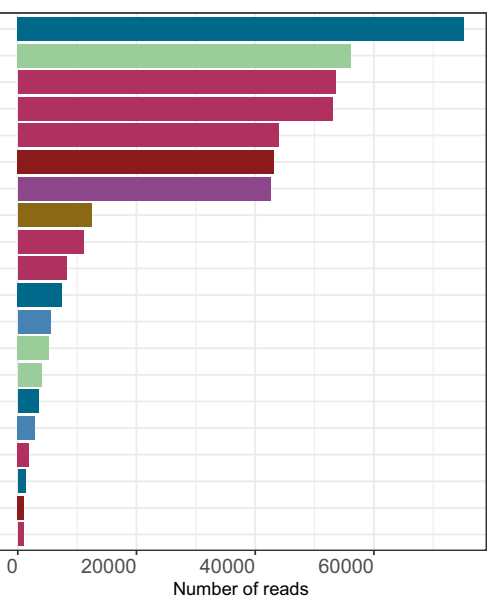

pico

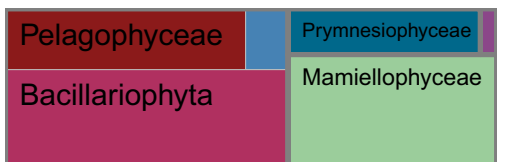

nano

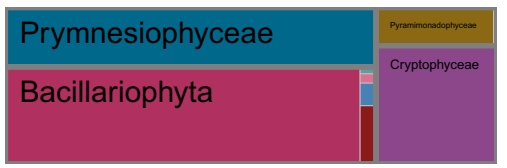

$0.2 \mu \mathrm{m}$
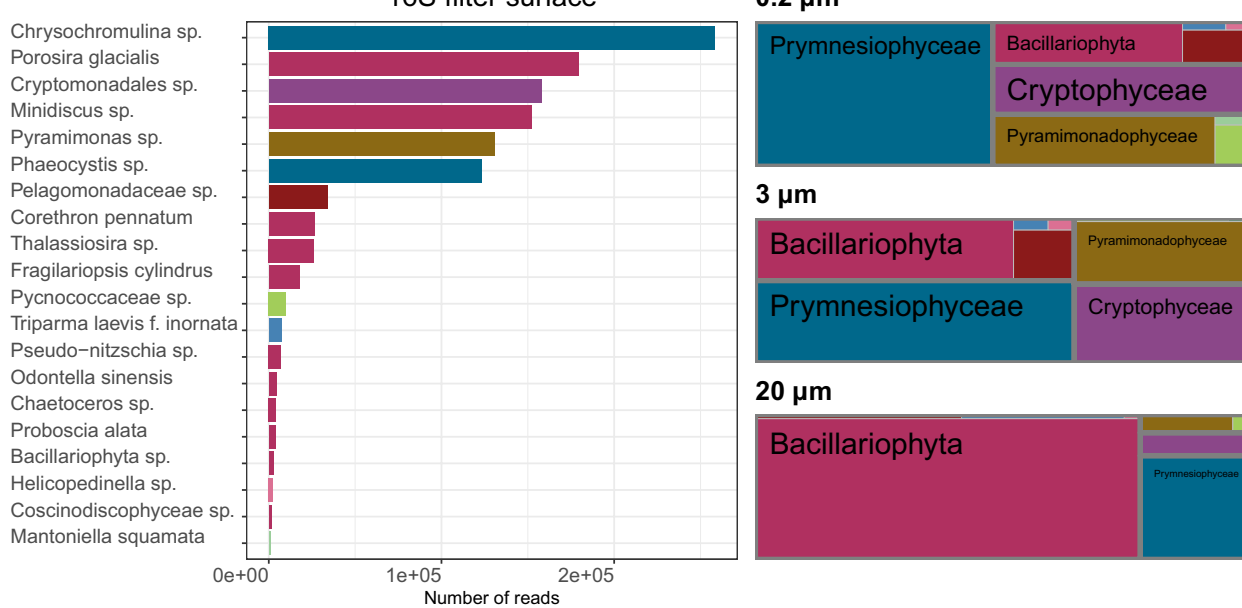

$3 \mu \mathrm{m}$

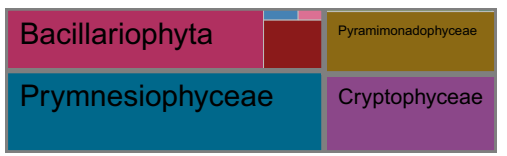

$20 \mu \mathrm{m}$

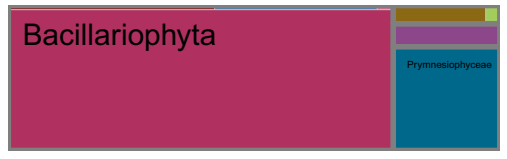

Figure 2. Community composition of phytoplankton (excluding dinoflagellates) at species level for surface samples $(5 \mathrm{~m})$ at station 6 in Fildes Bay. Top panel: 18S rRNA gene for filtered samples. Middle panel: 18S rRNA gene for sorted samples. Bottom panel: plastidial $16 \mathrm{~S}$ rRNA gene for filtered samples. Left side: abundance rank chart for major species. Right side: proportional area charts of relative abundance of classes by size fraction. 0.2 , 3 , and $20 \mu \mathrm{m}$ correspond to the $0.2-3,3-20$ and $>20 \mu \mathrm{m}$ size fractions, respectively. 
is also $100 \%$ identical to Shionodiscus oestrupii var. venrickiae strain CC03-15 (Genbank DQ514870) which has larger cells ${ }^{26}$ and therefore is probably mis-identified. Within Thalassiosira, the major ASV (asv_016_00006 also present in 18S-sort) is 100\% similar to Thalassiosira antarctica strain UNC1404 (KX253953) that was isolated off the WAP ${ }^{27}$. The second ASV (asv_016_00008 also present in 18S-sort) is 100\% identical to Thalassiosira minima strain RCC2265 which was isolated from the Arctic ${ }^{28}$ but also to strain RCC4586 which was isolated from Fildes Bay. In contrast, the next Thalassiosira ASV (asv_016_00016 also found in 18S-sort) does not match any existing sequence from cultures.

Within Pelagophyceae, two of the major ASVs (found in both 18 S rRNA datasets) share $99.7 \%$ similarity between them and do not match any described species or even cultured strain, suggesting that they corresponds to a new taxon. One less abundant ASV found in both $18 \mathrm{~S}$ rRNA datasets matches at $100 \%$ Pelagomonas calceolata, the type species of this class which is widespread in open oceanic waters ${ }^{29}$. Among Dictyochophyceae, the main ASV matches with $97.7 \%$ similarity Helicopedinella tricostata and with higher similarity (99.2\%) an undescribed strain (RCC2289) isolated from the Arctic ${ }^{30}$, suggesting that this ASV may correspond to a new species or even genus, while some of the other ASVs match the species Florenciella parvula and Pseudochattonella farcimen. Bolidophyceae were represented by Triparma laevis as well as environmental clades ${ }^{31}$. One uncultivated group MOCH-2 (Marine OCHrophyta) ${ }^{32}$ was found in many filtered and sorted samples although at low abundance.

Among Chlorophyta, Mamiellophyceae dominated with three major taxa: Micromonas polaris, Micromonas sp. clade B3 (uncultured) and Bathycoccus prasinos. While the main M. polaris ASVs (found in both 18S datasets) are $100 \%$ identical to Arctic strains, some minor M. polaris ASVs have a clearly different signature (Figure S5, arrows). On the other hand, the clade B3 ASVs matches the reference sequences from this clade ${ }^{33}$. Among Pyramimonadophyceae, the major ASV (present in both $18 \mathrm{~S}$ datasets) corresponds to the mixotrophic species Pyramimonas gelidicola. The other green algal classes (Trebouxiophyceae, Chlorophyceae, Ulvophyceae and Palmophyllophyceae) or orders (Pseudoscourfeldiales) were only minor contributors to the community.

Phaeocystis antarctica was the dominant Prymnesiophyceae (Haptophyta) species among 18S rRNA metabarcodes (Figure S6). However, in the sorted samples, we also found a minor ASV (asv_018_00239), not present in surface but only at depth (Table S2), with a $100 \%$ match to a strain of the arctic species Phaeocystis pouchetii. Surprisingly, the sequence of the three dominant Prymnesiophyceae ASVs in the 16S metabarcodes matches Chrysochromulina throndsenii with about $98 \%$ similarity, while they are matching P. antarctica with only $93 \%$ similarity. The fourth Prymnesiophyceae ASV (asv_017_00037) matched a P. antarctica strain at 100\%.

Among Cryptophyceae, the dominant species was Geminigera cryophila with small contributions of the genera Hemiselmis and Plagioselmis. The most abundant ASV (asv_016_00003) found in both 18S-filter and 18S-sort is $99.7 \%$ similar to a sequence from a recently isolate of $G$. cryophila from Antarctica (HQ111513) ${ }^{34}$. Another abundant Cryptophyceae ASV (asv_016_00113) is 100\% similar to several strains isolated from the Wedell and Ross Seas, some originating from the ice (e.g. RCC5152). Asv_016_00003 and 00113 are only 98.9\% similar. An ASV (asv_017_00002) assigned to Cryptomonadales was also abundant in the 16S dataset, maybe corresponding to G. cryophila as well, since it is $99.5 \%$ similar to a sequence from this species (AB073111), although it more similar to Teleaulax amphioxeia sequence (99.7\%).

The dominant taxa clearly varied depending on sample processing and the marker gene used (Fig. 2, left panels). Filtered samples using the $18 \mathrm{~S}$ rRNA gene were dominated by the diatoms Minidiscus sp., P. glacialis, F. cylindrus, T. antarctica and T. minima, the cryptophyte G. cryophila, an unknown pelagophyte, and B. prasinos. In sorted samples using the $18 \mathrm{~S}$ rRNA gene, the dominant taxa were P. antarctica, followed by M. polaris, Minidiscus sp., F. cylindrus, C. neogracilis (which was much less abundant in filtered samples) and an unknown pelagophyte. Finally, filtered samples analyzed with the 16S rRNA gene were dominated by species from the class Prymnesiophyceae (Chrysochromulina sp.) followed by the diatom P. glacialis, an unknown cryptophyte and Minidiscus sp.

We performed a more detailed analysis at the genus level to compute the number of taxa common to different approaches (Fig. 3A). We focused on the summer 2015, the only period for which we have comparable datasets. For the filtered samples, we only considered the 0.2 and $3 \mu \mathrm{m}$ fractions for comparison with the sorted samples which do not include the microphytoplankton. The number of shared genera detected by the three approaches was low (15, Fig. 3A). The number of genera only detected in one approach was highest for the $18 \mathrm{~S}$ filter dataset (28, in particular diatoms), followed by $16 \mathrm{~S}$ from filters (8, in particular diatoms and Dictyochophyceae), and $18 \mathrm{~S}$ from sorted samples (2).

Community size structure. In the larger size fractions $(20 \mu \mathrm{m}$ for filtered samples and nano for sorted samples), diatoms were always dominant whatever the metabarcoding approach used (Figs. 2 right side, and S2). In the smaller size fraction $(0.2 \mu \mathrm{m}$ and pico), the composition was more dependent on the approach. For example, Mamiellophyceae were important in both 18S-filter and 18S-sort data but almost absent in the 16S-filter data. In the filter data, Prymnesiophyceae were much more prevalent with $16 \mathrm{~S}$ compared with $18 \mathrm{~S}$, especially in the two smaller fractions (Figure S2). An analysis of the genera common to different size fractions (Fig. 3B) based on $18 \mathrm{~S}$ reveals that more than $65 \%$ of the genera were found in the three size-fractions (53), suggesting that size fractionation is not very efficient at strictly separating phytoplankton communities. When looking at sorted samples (Fig. 3C), the same observation prevailed as more than $55 \%$ of the genera were found in both pico and nano sorted fractions. This must be tempered however when looking at the abundance of each genus (Figure S2) with many genera abundant only in a single size fraction, although they may be present in the other size fractions at low abundance. For example, although Micromonas was present in all filtered size fractions and sorted samples (Supplementary Data S2), it was only abundant in the smallest size fractions (Figure S2). Similarly, Porosira sequences were found in all filtered size fractions (Supplementary Data S2), but dominant in the $20 \mu \mathrm{m}$ fraction and less abundant in the $0.2 \mu \mathrm{m}$ one. 

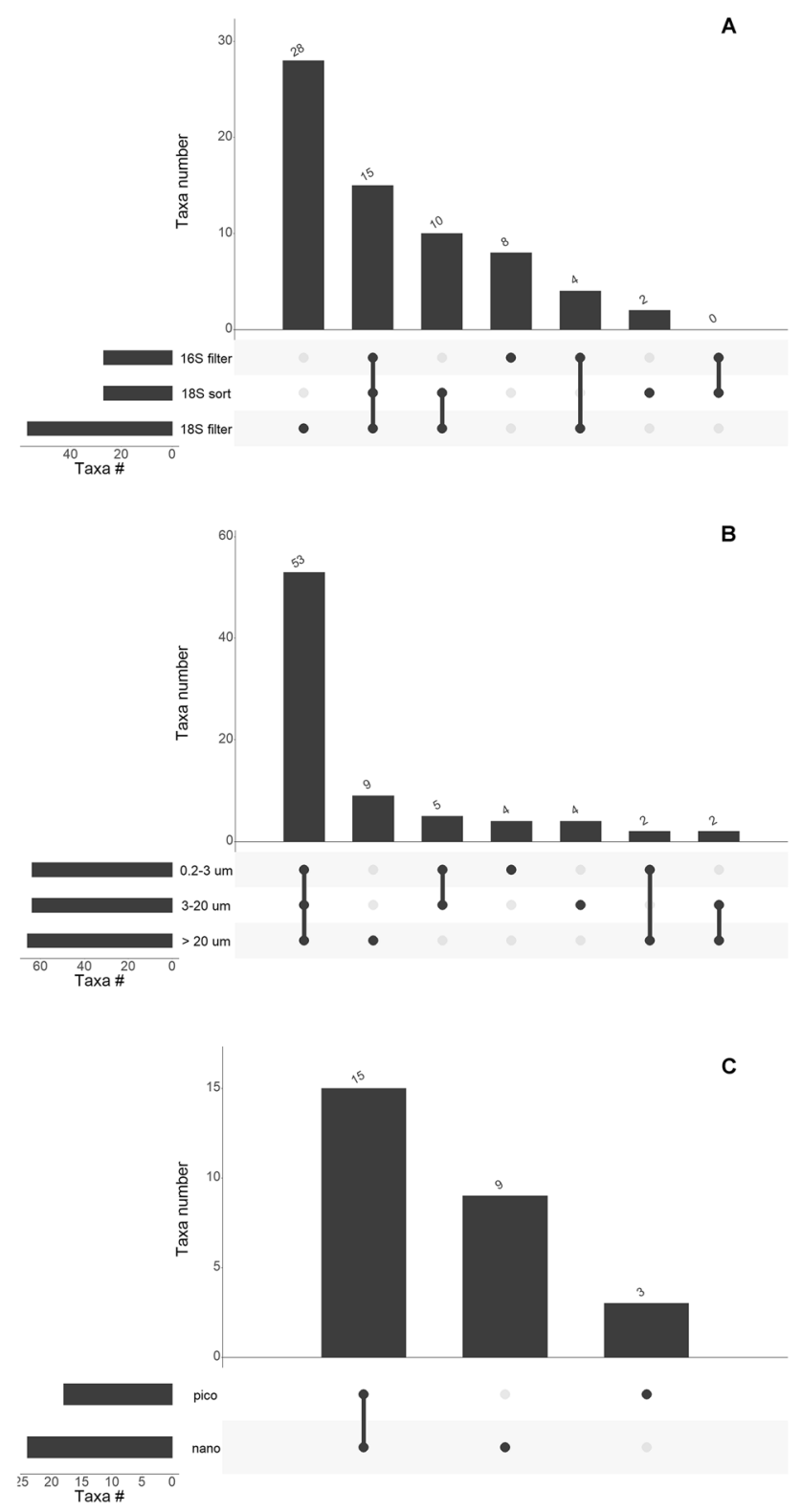

Figure 3. (A) Number of photosynthetic genera (excluding dinoflagellates) in common between different metabarcoding approaches for samples of the $0.2-3$ and 3-20 $\mu \mathrm{m}$ size fractions, collected during summer 2015. (B) Number of genera in common between different size-fraction for all $18 \mathrm{~S}$ rRNA gene samples. (C) Number of genera in common between different populations sorted by flow cytometry in summer 2015. Only taxonomic valid genera have been included.

Annual dynamics. The dynamics of the phytoplankton community throughout the year could only be followed from the filtered samples since sorted samples were only obtained in summer 2015. The most abundant photosynthetic classes showed a clear seasonal pattern with year to year variation (Figs. 4, S7 and S8). Focusing first on the 18S-filter dataset for which we have the largest number of samples (Fig. 4), we observed in the $0.2 \mu \mathrm{m}$ size-fraction, a succession from Bacillariophyta in summer to Pelagophyceae and Cryptophyceae in the autumn and spring, and then back to Bacillariophyta. The main species in this size fraction were Minidiscus sp. during summer, an unknown member of the Pelagophyceae during autumn and spring, and G. cryophyla during spring. The latter two taxa had also high abundance for the last samples taken in summer 2015. Sequences assigned to Mamiellophyceae were detected throughout all the sampled dates in the $0.2 \mu \mathrm{m}$ size-fraction. B. prasinos was present in the autumn and spring. In contrast, M. polaris was most prevalent during the summer 2015. In the 3 $\mu \mathrm{m}$ fraction, diatoms were only dominant during the summer and early fall, while Cryptophyceae were abundant throughout spring 2014 and summer 2015, and Pelagophyceae at the end of the autumn and in the spring. In this size fraction, the dominant diatom was Minidiscus sp. followed by F. cylindrus and T. minima, and the dominant cryptophyte was G. cryophyla. Finally in the $20 \mu \mathrm{m}$ fraction, diatoms were dominant throughout the year with the exception of the last sample taken in the autumn (May 2014) in which pelagophytes peaked. In 

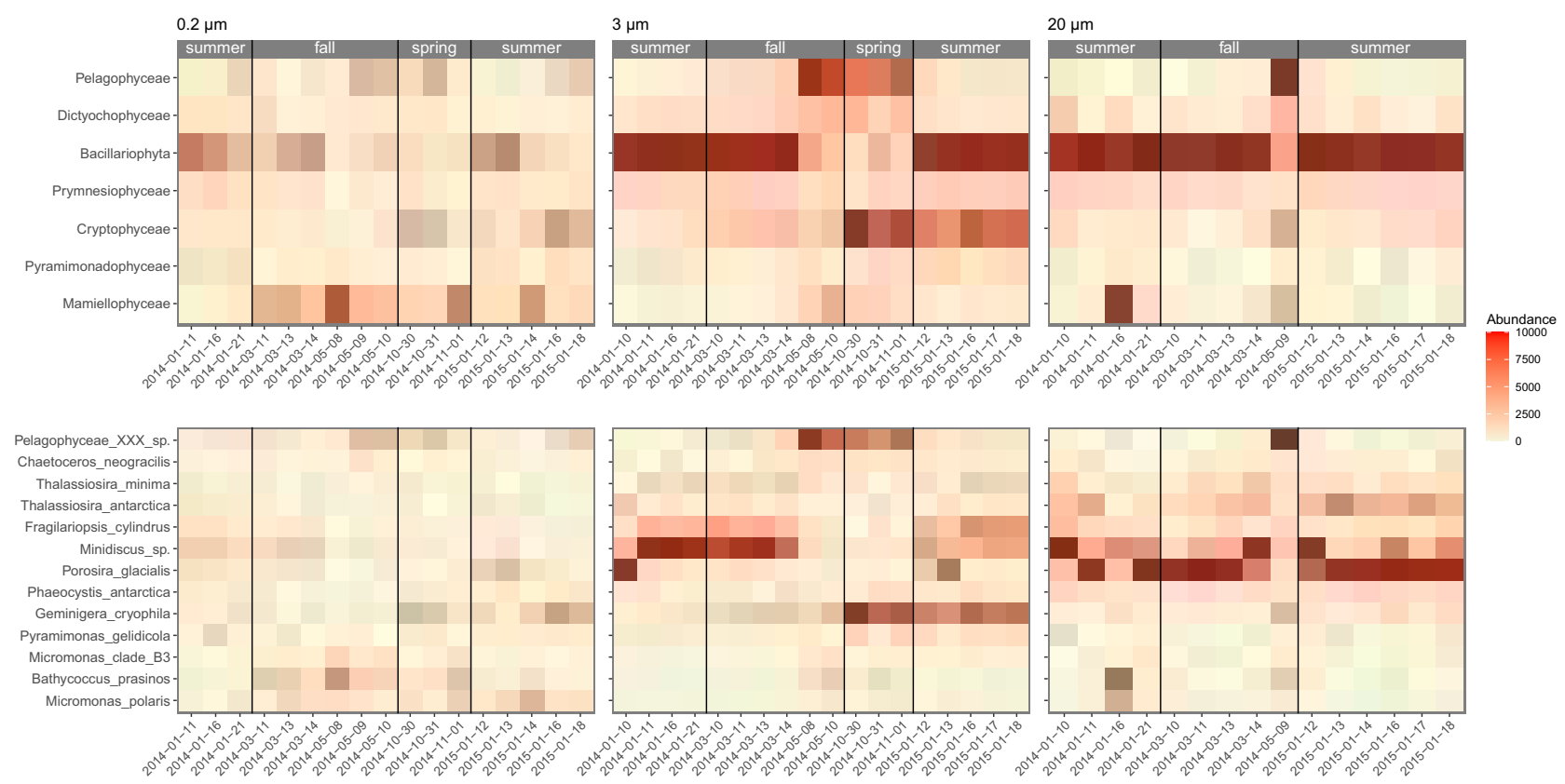

Figure 4. Change in the main phytoplankton groups (excluding dinoflagellates) at class (top) and species (bottom) levels in Fildes Bay during the study period based on the 18S rRNA gene in filtered surface samples. The color scale of the heatmap correspond to the normalized abundance of each taxon. Left: $0.2-3 \mu \mathrm{m}$. Middle: 3-20 $\mu \mathrm{m}$. Right: $>20 \mu \mathrm{m}$. Season delimitation corresponds to meteorological seasons.

this fraction, it was the larger diatom P. glacialis which was contributing most, followed by T. antarctica and the smaller Minidiscus sp. Interestingly when looking at the summer, there was some variation between the two years sampled. For example, Cryptophyceae were abundant in the summer in 2015 but less so in 2014 while it was the reverse for Dictyochophyceae. The 16S-filter dataset is interesting because while confirming the 18S-filter data, it provides better insight into the seasonal dynamics of Prymnesiophyceae and Pyramimonadophyceae that are masked by other taxonomic groups in the 18S-filter dataset (Figure S7). Prymnesiophyceae, especially prevalent in the pico and nano-phytoplankton fractions, are present throughout the year with a peak in the autumn while Pyramimonadophyceae, almost absent from the micro-phytoplankton, are restricted to the summer.

NMDS analysis based on Bray-Curtis dissimilarity for 18S-filter metabarcodes (Fig. 5 top) showed that samples group together according to season and size fraction, with summer samples displaying most scatter. Besides, taxa distribution also showed a seasonal variation, with Bacillariophyta as the dominant class in summer, and Prymnesiophyceae and Cryptophyceae in the other seasons. When available environmental parameters were fitted against the NMDS analysis, silica and nitrates appeared as key factors to differentiate summer vs. spring and autumn. A similar clustering pattern was observed when using the plastidial 16S rRNA gene (Figure S9). Clustering based on either season or size fraction was supported by ANOSIM as highly significant and size fraction had a stronger clustering effect than season (Table S4).

\section{Discussion}

The structure of the phytoplankton community (excluding dinoflagellates) determined using nuclear 18S rRNA gene vs. plastidial 16S rRNA gene displayed marked differences for some phytoplankton groups. For example, Prymnesiophyceae and Pyramimonadophyceae were more represented when using plastidial 16S versus nuclear $18 \mathrm{~S}$ while Mamiellophyceae were almost absent from the $16 \mathrm{~S}$ amplicon data. Pseudoscourfeldiales (Chlorophyta) only appeared in the $16 \mathrm{~S}$ data. The uncultured marine Ochrophyta $(\mathrm{MOCH})^{32}$, described from environmental $18 \mathrm{~S}$ rRNA sequences, was also only detected in the $18 \mathrm{~S}$ data since no $16 \mathrm{~S}$ rRNA sequences have been attributed to this uncultured clade (Supplementary Data S2). Differences in sequencing results between marker genes have been noted before ${ }^{20}$, and could be linked to primer bias, differences in amplification efficiency, variations in number of gene copies per genome ${ }^{35}$, differences in number of plastid genome copies per cell resulting from differences in the number of chloroplasts par cell ${ }^{36}$, or differential extraction yield for nuclear vs. plastidial DNA. This points out that the use of different marker genes allows to get a more complete image of phytoplankton communities.

Phytoplankton annual succession in Antarctic coastal waters. Phytoplankton composition in the WAP has been studied before ${ }^{8,9}$, but many of these studies relied on optical microscopy and pigment analysis $^{10,37-39}$ and focused only on the summer period ${ }^{40-42}$. Metabarcoding characterization in the WAP has been performed for samples from the PAL-TER, Fildes Bay (King George Island) and the RaTS ${ }^{43-45}$. However, none of these studies investigated the structure of the phytoplankton community at different seasons. In the present study, succession of different phytoplankton groups through the Austral seasons was evident. Bacillariophyta (diatoms) dominated mainly in summer and early autumn in all fractions; Mamiellophyceae were 

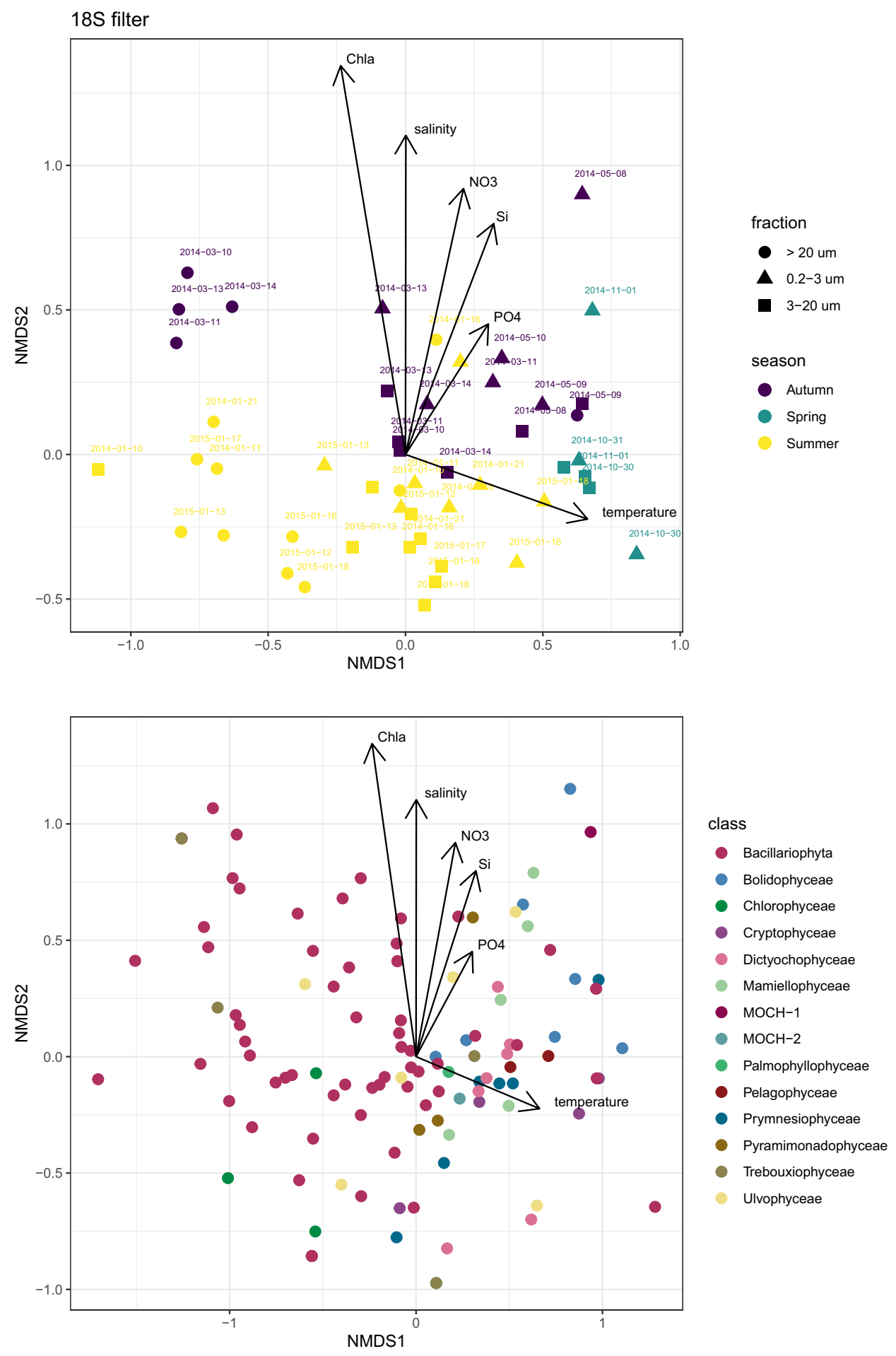

Figure 5. Non-metric multidimensional scaling (NMDS) analysis based on Bray-Curtis dissimilarities of the phytoplankton community composition (species) labeled by meteorological season (summer, autumn, and spring) and size fraction based of the $18 \mathrm{~S}$ gene of filtered samples. (Top) Samples. (Bottom) ASVs. Stress $=0.16$.

present in the pico-phytoplankton fraction throughout the year; Pelagophyceae, Dictyochophyceae and, to a lesser extent, Cryptophyceae dominated late autumn and spring samples, while Prymnesiophyceae increased at the end of summer in the small size fraction.

The most abundant genera of diatoms included Chaetoceros, Thalassiosira, Fragiliaropsis, Minidiscus and Porosira. These genera have been often observed in the WAP during summer months ${ }^{8,40}$, although the exact species may be different. For example, Garibotti et al. ${ }^{41}$ reported that different Fragilariopsis species could account together for up to $88 \%$ of diatom cell abundance at some sites in WAP during summer. In our study, the main 


\begin{tabular}{|c|c|c|c|c|c|c|c|c|c|c|c|c|c|c|}
\hline \multirow[b]{2}{*}{ Date } & \multirow[b]{2}{*}{ Season } & \multirow[b]{2}{*}{ CTD } & \multirow[b]{2}{*}{ Chl } & \multirow[b]{2}{*}{ FCM } & \multirow[b]{2}{*}{ Nutrients } & \multirow[b]{2}{*}{ Profile } & \multicolumn{3}{|c|}{ 18S rRNA filter } & \multicolumn{3}{|c|}{ 16S rRNA filter } & \multicolumn{2}{|c|}{$18 \mathrm{~S}$ rRNA sort } \\
\hline & & & & & & & $0.2 \mu \mathrm{m}$ & $3 \mu \mathrm{m}$ & $20 \mu \mathrm{m}$ & $0.2 \mu \mathrm{m}$ & $3 \mu \mathrm{m}$ & $20 \mu \mathrm{m}$ & Pico & Nano \\
\hline Jan 102014 & Summer & + & + & + & + & - & - & + & + & + & - & + & - & - \\
\hline Jan 112014 & Summer & + & + & + & + & - & + & + & + & + & + & + & - & - \\
\hline Jan 162014 & Summer & + & + & + & + & -- & + & + & + & + & + & + & - & - \\
\hline Jan 212014 & Summer & + & + & + & + & - & + & + & + & + & + & + & - & - \\
\hline Mar 102014 & Autumn & - & + & + & + & - & - & + & + & - & + & - & - & - \\
\hline Mar 112014 & Autumn & - & + & + & + & - & + & + & + & - & + & + & - & - \\
\hline Mar 132014 & Autumn & - & + & + & + & - & + & + & + & - & + & + & - & - \\
\hline Mar 142014 & Autumn & - & + & + & + & - & + & + & + & - & - & + & - & - \\
\hline May 82014 & Autumn & - & + & + & + & - & + & + & - & - & + & - & - & - \\
\hline May 92014 & Autumn & - & + & - & + & - & + & - & + & - & - & + & - & - \\
\hline May 102014 & Autumn & - & + & + & + & - & + & + & - & + & + & - & - & - \\
\hline Oct 302014 & Spring & - & + & + & + & - & + & + & - & + & + & - & - & - \\
\hline Oct 312014 & Spring & - & + & + & + & - & + & + & - & - & + & - & - & - \\
\hline Nov 12014 & Spring & - & + & + & + & - & + & + & - & + & + & + & - & - \\
\hline Jan 122015 & Summer & + & - & + & - & - & + & + & + & + & + & - & + & + \\
\hline Jan 132015 & Summer & + & + & + & + & + & + & + & + & + & + & + & + & + \\
\hline Jan 142015 & Summer & + & + & + & + & - & + & - & + & - & + & + & + & + \\
\hline Jan 162015 & Summer & + & + & + & + & + & + & + & + & + & + & + & + & + \\
\hline Jan 172015 & Summer & + & + & + & + & - & - & + & + & - & + & - & + & + \\
\hline Jan 182015 & Summer & + & + & + & + & + & + & + & + & + & - & + & + & + \\
\hline
\end{tabular}

Table 1. Samples collected. CTD corresponds to salinity and temperature data from CTD cast, Chl to Chlorophyll $a$, FCM to flow cytometry and Profile to vertical profile sampling. 18S and 16S rRNA columns correspond to metabarcoding analyses for nuclear $18 \mathrm{~S}$ and plastidial $16 \mathrm{~S}$ rRNA gene. Crosses correspond to samples that were collected while the minus signs correspond to missing samples.

\begin{tabular}{|l|l|l|l|l|l|l|}
\hline ID & Gene & Sample processing & Fractions & Sample number & Photo ASVs & Photo reads (median) \\
\hline 16 & $18 \mathrm{~S}$ rRNA nuclear & Filtered & $0.2,3,20 \mu \mathrm{m}$ & 120 & 562 & 22,825 \\
\hline 17 & $16 \mathrm{~S}$ rRNA plastidial & Filtered & $0.2,3,20 \mu \mathrm{m}$ & 100 & 357 & 33,220 \\
\hline 18 & $18 \mathrm{~S}$ rRNA nuclear & Sorted & pico, nano & 40 & 187 & 27,725 \\
\hline
\end{tabular}

Table 2. Summary of the metabarcoding data sets analyzed. ID corresponds to the dataset identifier. "Photo ASVs" and "Photo reads" corresponds to the number of ASVs and the median number of reads for all samples from each data set assigned to photosynthetic taxa.

species was F. cylindrus while F. sublineata was also present but much less abundant (Table S2). We failed to observe other Fragilariopsis species often associated to WAP spring/summer blooms, such as F. pseudonana, F. ritscheri and F. curta ${ }^{41,46}$. Minidiscus chilensis has been previously reported at $\mathrm{WAP}^{8}$ as a characteristic diatom of early-summer production, comprising a high proportion of phytoplankton biomass ${ }^{40}$ and carbon transport to sea-floor ${ }^{47}$. However, in contrast to the reported early-summer blooms of Minidiscus in Ryder Bay ${ }^{40}$ and Bransfield Strait ${ }^{47}$, we detected a high abundance of Minidiscus in our summer and early autumn samples.

In the pico-phytoplankton fraction, Mamiellophyceae were present throughout the year and dominated specific samples from autumn and summer, although the most abundant species, $M$. polaris, has been rarely reported in Antarctic waters, in contrast to its dominance within the Arctic pico-phytoplankton (see next section). In the pico- and nano-phytoplankton fractions, Pelagophyceae became abundant after diatoms had decreased towards the end of autumn (Fig. 4). Pelagophyceae is a class with only a few species described, mostly belonging to the pico-plankton size range ${ }^{48}$, that was initially described from strains isolated in tropical and temperate waters ${ }^{49}$. However, this class has been found later in polar environments ${ }^{23,44,50}$ and recently novel nano-plankton sized strains have been isolated from polar waters, which probably correspond to several yet undescribed species ${ }^{30,51}$.

Within Prymnesiophyceae, the genus Phaeocystis is considered a key-player in Antarctic waters not only during the highly productive summer, but also during autumn and winter months ${ }^{52}$. P. antarctica has a wide presence in the Southern Ocean ${ }^{53}$ and is linked to increased carbon transport to deeper waters ${ }^{14,54}$. An alternation between diatoms and P. antarctica, as reflected here in the 16S-filter prymnesiophytes (Figure S7), has been reported as a consequence to disturbances in the water column structure ${ }^{12,55}$, as the latter benefits from deeper mixed layers and weakly stratified waters, due to its ability to maintain its photosynthetic rates in low light environments ${ }^{14}$ and to quickly acclimate to different light regimes even under iron limitation ${ }^{56}$. The shift of prymnesiophytes from the 3 to the $20 \mu \mathrm{m}$ size fraction in the early summer and late autumn 2014 (Figure S7) 
could be due to the formation of Phaeocystis colonies of large size that were retained by the $20 \mu \mathrm{m}$ filter. Differences observed between nuclear 18S rRNA and plastidial 16S rRNA Phaeocystis read abundance might be a result of this photo-acclimation process ${ }^{36}$.

As light availability decreases towards autumn/winter, mixotrophy becomes a possible strategy for photosynthetic organisms to survive during the long period of darkness. Few studies however have been performed on this process ${ }^{57}$. In the present study, three groups have been reported as possessing mixotrophic species: cryptophytes, dictyochophytes and Pyramimonadophyceae. Cryptophyte blooms are considered a secondary stage of the seasonal phytoplankton succession, developing after sea-ice edge diatom blooms, and may present a significant inter-annual variability at WAP, being favored by years of earlier sea-ice retreat ${ }^{3}$. Our data are coherent with this pattern as cryptophytes were most abundant in the spring, when the sea-ice melts. Interestingly, they remained abundant in the summer of 2015 but not in 2014, pointing to some inter-annual variability. G. cryophila was the main cryptophyte species in this study, and has been determined to be mixotrophic ${ }^{57}$. It has been previously reported at WAP ${ }^{12}$, including as a dominant taxa ${ }^{44}$, and has probably a circum-Antarctic distribution ${ }^{34}$, linked to warmer, nutrient-depleted post-bloom conditions ${ }^{57}$. Dictyochophyceae were most abundant in the spring under low light conditions. Some of the main ASVs were assigned to Pedinellales, which are known mixotrophs ${ }^{58}$, and also to the genus Florenciella, which has been very recently determined to be mixotrophic feeding on heterotrophic bacteria as well as cyanobacteria ${ }^{59}$. In contrast, Pyramimonadophyceae which harbor several mixotrophic species ${ }^{57,60}$ were most abundant in the summer, suggesting that the occurring species were probably not mixotrophic.

Antarctic versus Arctic phytoplankton communities. The Arctic and Antarctic marine ecosystems share many similarities due to the constraints of solar radiation input at high latitudes and a phytoplankton phenology connected to sea-ice formation and melting. This similarity is also seen at the taxonomic level, as many of the dominant taxa observed in the present study shared highly related or identical 18S rRNA sequences to Arctic species. Bipolarity has been long observed on planktonic marine organisms ${ }^{61,62}$, and implies transequatorial genetic flow and organismal dispersal, mainly via ocean currents. Bipolar species might however thrive differently in the Arctic and Antarctic. In a study investigating bipolar protists based on $18 \mathrm{~S}$ rRNA, Wolf et al. ${ }^{63}$ observed that only two OTUs that were not part of the rare biosphere, i.e. that accounted for more than $1 \%$ of total reads, were found in both poles: an unknown alveolate and Micromonas.

Although the dominant component of the picophytoplankton in Arctic waters in summer ${ }^{23,64}$, M. polaris has been rarely reported from Antarctic waters ${ }^{65,66}$, and even then, in low abundance ${ }^{39,44}$. In the present study $M$. polaris was detected in 42 samples, reaching up to $47 \%$ of photosynthetic reads in a single sample (Table S3). Two other Micromonas clades have been detected in Arctic or sub-Arctic waters, clade B3 ${ }^{33}$, also detected here, and $M$. commoda clade $\mathrm{A} 2^{67}$. To the best of our knowledge, this is the first study to report this genus as a major player within the austral pico-phytoplankton. It is unclear if the unprecedented high abundance of $M$. polaris in Antarctic waters is related to a local and transient phenomena or part of a greater change associated with global climate patterns, since this species seems to be favored by increasing temperatures, enhanced water column stratification and ocean acidification ${ }^{68-70}$. We have also detected a third Micromonas signature, which could potentially represent a novel Micromonas clade that could be endemic to Antarctica (Figure S5). Another Mamiellophyceae, $B$. prasinos, is widely distributed in the world's oceans with two ecotypes reported so far, which share identical $18 \mathrm{~S}$ rRNA sequences but differ in their genomes and distribution ${ }^{71,72}$. In the present study, $B$. prasinos was abundant during autumn and spring, whereas $M$. polaris was more abundant during spring and summer. Interestingly, Micromonas clade B3 seems to follow seasonal dynamics that are closer to B. prasinos than to $M$. polaris. These seasonal dynamics seem to be analogous to what was observed in the Arctic, where a seasonal succession occurs between the two taxa with increased abundance of the Bathycoccus in winter ${ }^{67}$, possibly due to differences in loss rates, viral defense efficiency or mixotrophic activity between the two species.

The large centric diatom Porosira glacialis, which has a bipolar distribution, was the most abundant taxon in the present data set, mainly in the $20 \mu \mathrm{m}$ size fraction, reaching up to $74 \%$ of total reads in a given sample (Table S3). In the Arctic, P. glacialis has been reported as highly abundant in spring samples, co-occurring with Thalassiosira gravida/antarctica var. borealis ${ }^{73}$. A similar trend was observed in Antarctica, where P. glacialis was reported along with T. antarctica to make up to $90 \%$ of total phytoplankton biomass on King George Island during episodic events ${ }^{74}$. These diatoms are considered summer/autumn bloom species which share similar ecological preferences, being found together in diatom assemblages from paleontological samples ${ }^{75}$. The alternation between $P$. glacialis and T. antarctica dominance seems to be linked to sea-ice concentration, as $P$. glacialis higher abundances are correlated to cooler environmental conditions ${ }^{76}$. Although being often reported from both poles, Arctic and Antarctic strains of $P$. glacialis might differ in their $28 \mathrm{~S}$ rRNA sequence, indicating a possible genetic divergence ${ }^{28}$.

C. neogracilis is a species complex with identical $18 \mathrm{~S}$ rRNA sequences, common in Arctic surface waters in the summer ${ }^{23,28,64}$. The $C$. neogracilis partial $18 \mathrm{~S}$ rRNA sequence obtained in the present study is identical to a previously isolated C. neogracilis Antarctic strain (AnM0002), which is morphologically similar to, but phylogenetically distinct from, Arctic strains. Balzano et al. ${ }^{28}$ sequenced the full $18 \mathrm{~S}$ rRNA gene of the AnM0002 strain and reported a $98.9 \%$ sequence identity with Arctic C. neogracilis strains, suggesting the former could be an undescribed Chaetoceros species, possibly with an endemic Antarctic distribution.

Thalassiosira spp. is a well-known and important component of both Arctic $^{77}$ and Antarctic ${ }^{8,9}$ phytoplankton communities. In the present study T. minima was the most conspicuous species among the genus Thalassiosira, observed in 49 samples (Table S3). T. minima is considered a cosmopolitan species mostly observed in temperate waters $^{77,78}$ and mostly excluded from polar regions except for one report in the Arctic Beaufort Sea ${ }^{28}$. Surprisingly, T. minima does not seem to have been reported in the Southern Ocean which could point out to a recent invasion linked to global change. 
Phaeocystis is an ubiquitous genus, with a relatively well-defined biogeographic distribution for some species ${ }^{79}$. $P$. pouchetii is mainly found in Arctic and $P$. antarctica in many regions of the Southern Ocean ${ }^{53,79,80}$, while $P$. globosa is mostly found in temperate and tropical waters ${ }^{81}$. Although the main ASVs found in this study matched $P$. antarctica confirming numerous reports, we also found one ASV matching P. pouchetii, the Arctic species, and which was only found at depth (Table S2), suggesting that this latter species might be bipolar.

Final considerations. The WAP is undergoing accelerated environmental changes compared to the rest of Antarctic regions, being more susceptible to warming and sea-ice $\operatorname{loss}^{82}$ due to increased maritime influence ${ }^{83}$. The decreasing sea-ice extent in both time and space influences phytoplankton diversity and production ${ }^{39}$, highlighting the need for year-round ecological assessments of the phytoplankton structure and possible climaterelated disturbances. The present study provides evidence that classes such as Mamiellophyceae and Pelagophyceae, mostly present in the pico- and nanophytoplankton may have a greater ecological importance in the WAP than previously thought, and that a combination of methods is needed to investigate the full extent of phytoplankton diversity in this region.

\section{Methods}

Study site and sampling. Surface seawater samples $(5 \mathrm{~m})$ were collected from Station 6 in Fildes Bay, King George Island, Western Antarctic Peninsula $\left(62^{\circ} 12^{\prime} 11^{\prime \prime} \mathrm{S}, 58^{\circ} 55^{\prime} 15^{\prime \prime} \mathrm{W}\right)$ using a $5 \mathrm{~L}$ Niskin bottle, in January, March, May, and October 2014, and January 2015 (Table 1). In January 2015, vertical profiles were also obtained by sampling at 4 additional depths $(15,20,25$ and $50 \mathrm{~m})$. Samples were prefiltered on board using a $100 \mu \mathrm{m}$ Nitex mesh, stored in sterile plastic carboys and kept in darkness until processing (less than 2 hours). Once in the laboratory, sub-samples for $\mathrm{Chl} a$, flow cytometry, nutrients and molecular analyses were taken. Temperature (SST), salinity and PAR measurements were obtained using a CTD SBE 911 plus (SeaBird Electronics) equipped with an auxiliary biospherical PAR sensor.

Nutrients. Sub-samples of filtered seawater were collected in $15 \mathrm{~mL}$ polypropylene tubes and stored at $-20^{\circ} \mathrm{C}$ until analysis. Concentrations of nitrate $\mathrm{NO}_{3}^{-}$, phosphate $\mathrm{PO}_{4}^{3-}$ and silicate $\mathrm{SiO}_{3}^{2-}$ were determined as described previously ${ }^{84}$.

Chlorophyll $\boldsymbol{a}$ determination. Total Chl $a$ was determined from triplicate $100 \mathrm{~mL}$ sub-samples. Biomass $(<100 \mu \mathrm{m})$ was collected on $25 \mathrm{~mm}$ diameter GF/F filters (Whatman) in the dark immediately after the samples arrived to the laboratory. Pigments were extracted in $90 \%$ acetone for $24 \mathrm{~h}$ at $-20^{\circ} \mathrm{C}$ and analysed on a Turner Designs Trilogy fluorometer, according to the method of Holm-Hansen et al. ${ }^{85}$. Calibration was made with a Chl $a$ standard (Sigma-Aldrich).

Phytoplankton cell counts by flow cytometry. Sub-samples of $1.35 \mathrm{~mL}$ were taken in triplicates, fixed with $150 \mu \mathrm{L}$ of fixative (final concentrations: $1 \%$ paraformaldehyde, $0.5 \%$ glutaraldehyde, $100 \mathrm{mM}$ sodium borate, $\mathrm{pH}$ 8.4), incubated for $20 \mathrm{~min}$ at room temperature and fast frozen in liquid nitrogen. Cells were enumerated using an Accuri C6 Plus flow cytometer (Becton Dickinson) equipped with a combination of blue 488 $\mathrm{nm}$ and red $640 \mathrm{~nm}$ lasers. Photosynthetic pico-eukaryotes (PPE), photosynthetic nano-eukaryotes (PNE) and cryptophytes (CRY) were differentiated by forward and side light scatters and trigger pulse width from the 488 $\mathrm{nm}$ laser, and red $(>670 \mathrm{~nm})$ and orange $(585 / 40 \mathrm{~nm})$ fluorescence detection from 488 and $640 \mathrm{~nm}$ laser. Marine cyanobacteria (Prochlorococcus, Synechococcus) were never detected. Each sample was run at an average flow rate of $81 \mu \mathrm{L} \mathrm{min}{ }^{-1}$ for $3 \mathrm{~min}$. Flow rate was calculated by measuring the difference of volume of pre-filtered water after run for 10 minutes at the fast flow speed. Cell count analyses were performed using BD CSampler Plus software.

Sorting by flow cytometry. Samples $(1.5 \mathrm{~mL})$ for cell sorting by flow cytometry were collected in cryotubes with 10\% DMSO (final concentration) and $0.01 \%$ Pluronic F68 (final concentration) ${ }^{86}$, flash-frozen in liquid nitrogen, and stored at $-80^{\circ} \mathrm{C}$ until analysis at the Station Biologique de Roscoff, France. Samples were analyzed and sorted using a FACSAria flow cytometer (Becton Dickinson, San Jose, CA). Photosynthetic pico and nanoeukaryotes populations were selected based on light scatter, orange phycoerythrin, and red chlorophyll fluorescence and sorted in purity mode, directly into Eppendorf tubes containing Tris-EDTA lysis buffer (Tris $10 \mathrm{mM}$, EDTA $1 \mathrm{mM}$, and 1.2\% Triton, final concentration). Tris- $\mathrm{HCl} 50 \mathrm{mM}, \mathrm{pH}$ 8.0, $\mathrm{NaCl} 10 \mathrm{mM}$ was used as sheath liquid. Sheath pressure was set at $70 \mathrm{PSI}$ and nozzle frequency was $90 \mathrm{KHz}$ with a deflection voltage of $6000 \mathrm{~V}^{86}$. Sheath fluid samples were collected and analyzed as negative controls in all subsequent steps, including sequencing, to test for contamination in the flow sorting process ${ }^{87}$.

Biomass collection and DNA extraction. Samples of $4.5 \mathrm{~L}$ of seawater were serially size-fractionated using a peristaltic pump (Cole-Palmer) with $47 \mathrm{~mm}$ diameter Swinnex filter holder (Millipore), and $20 \mu \mathrm{m}$ (Nylon, Millipore), $3 \mu \mathrm{m}$ and $0.2 \mu \mathrm{m}$ (Poly-carbonate, Millipore) pore size filters. Filters were stored in $2 \mathrm{~mL}$ cryovials in liquid nitrogen or at $-80^{\circ} \mathrm{C}$ until DNA extraction. For DNA extraction, filters were thawed and half of the filters were cut into small pieces, while the other half was kept at $-20^{\circ} \mathrm{C}$ as backup. All steps were performed under sterile conditions. Each half-filter was incubated in lysis buffer (TE $1 \mathrm{x} / \mathrm{NaCl} 0.15 \mathrm{M}$ ), with $10 \%$ SDS and $20 \mathrm{mg} \mathrm{mL}^{-1}$ proteinase $\mathrm{K}$ at $37^{\circ} \mathrm{C}$ for $1 \mathrm{~h}$. DNA was extracted using $5 \mathrm{M} \mathrm{NaCl}$ and hexadecyltrimethyl-ammonium bromide $(\mathrm{CTAB})$ extraction buffer $(10 \% \mathrm{CTAB}, 0.7 \% \mathrm{NaCl})$ and incubated at $65^{\circ} \mathrm{C}$ for $10 \mathrm{~min}$ before protein removal using a conventional phenol- chloroform method. DNA was precipitated using 
ethanol at $-20^{\circ} \mathrm{C}$ for $1 \mathrm{~h}$ and re-suspended in $50 \mu \mathrm{L}$ Milli-Q water (Millipore) $)^{12}$. DNA integrity was evaluated by agarose gel electrophoresis and quantified using a fluorometric assay (Qubit 2.0 fluorometer).

Metabarcoding of filtered samples. For general eukaryotes, the V4 region of $18 \mathrm{~S}$ rRNA gene was amplified using primer pair TAReuk454FWD1 (CCAGCASCYGCGGTAATTCC) and V4 18S Next.Rev (ACT TTCGTTCTTGATYRATGA $)^{88}$. For photosynthetic eukaryotes, plastidial $16 \mathrm{~S}$ rRNA gene was amplified using primer pair Pla491F (GAGGAATAAGCATCGGCTAA) ${ }^{19}$ and PP936R (CCTTTGAGTTTCAYYCTTGC) (https ://biomarks.eu/pp936r). PCR reactions were performed in triplicate in $50 \mu \mathrm{L}$ final volumes with Taq buffer 1X final concentration, $2 \mathrm{mM}$ of $\mathrm{MgCl}_{2}, 0.2 \mathrm{nM}$ of dNTPs, $0.2 \mu \mathrm{M}$ of each primer, 2.5 units of GoTaq Flexi DNA Polymerase (Fermelo) and approximately $5 \mathrm{ng} \mu \mathrm{L}^{-1}$ of DNA. Amplification conditions were $10 \mathrm{~min}$ of initial denaturation at $94^{\circ} \mathrm{C}, 30$ cycles of $94^{\circ} \mathrm{C}$ for $45 \mathrm{~s}, 57^{\circ} \mathrm{C}\left(\mathrm{V} 418 \mathrm{~S}\right.$ rRNA) or $62^{\circ} \mathrm{C}\left(16 \mathrm{~S}\right.$ rRNA) for $45 \mathrm{~s}$ and $72^{\circ} \mathrm{C}$ for $1.25 \mathrm{~min}$, followed by a final extension of $72^{\circ} \mathrm{C}$ for $10 \mathrm{~min}$. Amplicons were visualized on a $2 \%$ agarose gel (TAE 1X) and purified using the Wizard SV Gel and PCR Clean-Up System.

Metabarcoding of sorted samples. DNA from sorted cells was extracted by one cycle of freezing and thawing in liquid nitrogen a prior the PCR reaction. PCR conditions were as described in Gérikas Ribeiro et al. ${ }^{87}$. Because of the small number of cells collected (from to 500 to 6500), sorted samples required a nested amplification with the first round of PCR done using the 18S rRNA gene primers 63F (ACGCTTGTCTCAAAGATTA) and $1818 \mathrm{R}$ (ACGGAAACCTTGTTACGA) ${ }^{89}$ with the following $10 \mu \mathrm{L}$ mix: $5 \mu \mathrm{L}$ KAPA HiFi HotStart ReadyMix $2 \mathrm{x}, 0.3 \mu \mathrm{M}$ final concentration of each primer, $1 \mu \mathrm{L}$ of cells. Thermal conditions were: $95^{\circ} \mathrm{C}$ for $5 \mathrm{~min}$, followed by 25 cycles of $98^{\circ} \mathrm{C}$ for $20 \mathrm{~s}, 52^{\circ} \mathrm{C}$ for $30 \mathrm{~s}, 72^{\circ} \mathrm{C}$ for $90 \mathrm{~s}$, and a final cycle of $72^{\circ} \mathrm{C}$ for $5 \mathrm{~min}$. For the second round: $12.5 \mu \mathrm{L}$ KAPA HiFi HotStart ReadyMix 2x, $0.3 \mu \mathrm{M}$ final concentration of the same primers as described above (TAReuk454FWD1 and V4 18S Next.Rev), $2.5 \mu \mathrm{L}$ of first round product and water for a $25 \mu \mathrm{L}$ reaction. Thermal conditions were: $95^{\circ} \mathrm{C}$ for $3 \mathrm{~min}$, followed by 25 cycles of $98^{\circ} \mathrm{C}$ for $20 \mathrm{~s}, 65^{\circ} \mathrm{C}$ for $1 \mathrm{~min}, 72^{\circ} \mathrm{C}$.

Amplicon sequencing. Amplicons were sequenced on an Illumina Miseq using a 250 cycles Miseq kit v. 2 at the Genotoul GeT core facility (Toulouse, France) for filtered samples and at the GenoMer platform (Roscoff, France) for sorted samples. The final amplicon sequencing dataset (Table 2) contained 120 filtered samples (data set \# 16) and 40 sorted samples for the 18S rRNA gene (data set \# 18), and 100 filtered for the plastidial 16S rRNA gene (data set \# 17). See Supplementary Data S1 for list of samples. Data have been deposited to GenBank SRA under project numbers PRJNA645244 for 18S rRNA and PRJNA645261 for 16S rRNA.

Sequence processing. The three different datasets $(16,17$ and 18) were processed independently. Primer sequences were first removed using cutadapt ${ }^{90}$ with the default parameters (maximum error rate $=10 \%$ ). Amplicon processing was performed under the $\mathrm{R}$ software ${ }^{11}$ using the dada2 package ${ }^{24}$. Reads were filtered with the following parameters: truncLen and minLen $=c(230,230)$, truncQ $=2$, maxEE $=c(10,10)$. Merging of the forward and reverse reads was done with the mergePairs function using the default parameters (minOverlap = 12 , maxMismatch $=0$ ). Chimeras were removed using removeBimeraDenovo with default parameters. Taxonomic assignation of ASVs was performed using the assignTaxonomy function from dada2 against the $\mathrm{PR}^{2}$ database $^{92}$ version 4.12 (https://pr2-database.org/) which contains both 18S rRNA and plastidial 16S rRNA reference sequences, the latter originating from a curated version of Phytoref ${ }^{93}$. We selected only ASVs corresponding to photosynthetic groups (divisions Chlorophyta, Cryptophyta, Rhodophyta, Haptophyta and Ochrophyta with the exception of Chrysophyceae, Bangiophyceae, Florideophyceae, Xanthophyceae and Phaeophyceae that are known to be either heterotrophic or only contain macroalgae). The number of photosynthetic ASVs and the median number of reads per dataset is provided in Table 2.

Data analysis. The following R packages were used for data analysis: tidyr ${ }^{94}$ for filtering and plotting, treemapify $y^{95}$ for treemaps, phyloseq ${ }^{96}$ for heatmaps and NMDS, vegan ${ }^{97}$ for ANOSIM (ANalysis Of SIMilarity) of the influence of season and size fraction and $u p s e t R^{98}$ for upset plots. The number of reads in each sample was first normalized by the median sequencing depth for each dataset (Table 2).

Data availability

GenBank project numbers PRJNA645244 and PRJNA645261.

\section{Code availability}

https://github.com/vaulot/Paper-Trefault-2020-Antarctica.

Received: 27 October 2020; Accepted: 22 December 2020

Published online: 14 January 2021

\section{References}

1. Smetacek, V. \& Nicol, S. Polar ocean ecosystems in a changing world. Nature 437, 362-368. https://doi.org/10.1038/nature04161 (2005).

2. Browning, T. J. et al. Nutrient regimes control phytoplankton ecophysiology in the South Atlantic. Biogeosciences 11, 463-479. https://doi.org/10.5194/bg-11-463-2014 (2014).

3. Garibotti, I. A., Vernet, M. \& Ferrario, M. E. Annually recurrent phytoplanktonic assemblages during summer in the seasonal ice zone west of the Antarctic Peninsula (Southern Ocean). Deep-Sea Res. Part I Oceanogr. Res. Pap. 52, 1823-1841. https://doi. org/10.1016/j.dsr.2005.05.003 (2005). 
4. Clem, K. R. et al. Record warming at the South Pole during the past three decades. Nat. Clim. Change 10, 762-770. https://doi. org/10.1038/s41558-020-0815-z (2020).

5. Martinson, D. G., Stammerjohn, S. E., Iannuzzi, R. A., Smith, R. C. \& Vernet, M. Western Antarctic Peninsula physical oceanography and spatio-temporal variability. Deep-Sea Res. Part II Top. Stud. Oceanogr. 55, 1964-1987. https://doi.org/10.1016/j. dsr2.2008.04.038 (2008).

6. Schofield, O. et al. Changes in the upper ocean mixed layer and phytoplankton productivity along the West Antarctic Peninsula. Philos. Trans. R. Soc. A Math. Phys. Eng. Sci. 376, 20170173. https://doi.org/10.1098/rsta.2017.0173 (2018).

7. Kim, H. et al. Inter-decadal variability of phytoplankton biomass along the coastal West Antarctic Peninsula. Philos. Trans. R. Soc. A Math. Phys. Eng. Sci. 376, 20170174. https://doi.org/10.1098/rsta.2017.0174 (2018).

8. Lange, P. K., Ligowski, R. \& Tenenbaum, D. R. Phytoplankton in the embayments of King George Island (Antarctic Peninsula): a review with emphasis on diatoms. Polar Rec. 54, 158-175. https://doi.org/10.1017/S0032247418000232 (2018).

9. Kopczynska, E. Phytoplankton variability in Admiralty Bay, King George Island, South Shetland Islands: six years of monitoring. Pol. Polar Res. 29, 117-139 (2008).

10. Biggs, T. E. et al. Antarctic phytoplankton community composition and size structure: importance of ice type and temperature as regulatory factors. Polar Biol. 42, 1997-2015. https://doi.org/10.1007/s00300-019-02576-3 (2019).

11. Assmy, P. et al. Leads in Arctic pack ice enable early phytoplankton blooms below snow-covered sea ice. Sci. Rep. 7, 1-9. https:// doi.org/10.1038/srep40850 (2017).

12. Egas, C. et al. Short timescale dynamics of phytoplankton in Fildes Bay, Antarctica. Antarct. Sci. 29, 217. https://doi.org/10.1017/ S0954102016000699 (2017).

13. Delmont, T. O., Hammar, K. M., Ducklow, H. W., Yager, P. L. \& Post, A. F. Phaeocystis antarctica blooms strongly influence bacterial community structures in the Amundsen Sea polynya. Front. Microbiol. 5, 1-13. https://doi.org/10.3389/fmicb.2014.00646 (2014).

14. Arrigo, K. R. et al. Phytoplankton community structure and the drawdown of nutrients and $\mathrm{CO}_{2}$ in the Southern Ocean. Science 283, 365-367. https://doi.org/10.1126/science.283.5400.365 (1999).

15. Lin, Y. et al. Specific eukaryotic plankton are good predictors of net community production in the Western Antarctic Peninsula. Sci. Rep. 7, 1-11. https://doi.org/10.1038/s41598-017-14109-1 (2017).

16. Alcamán-Arias, M. E., Farías, L., Verdugo, J., Alarcón-Schumacher, T. \& Díez, B. Microbial activity during a coastal phytoplankton bloom on the Western Antarctic Peninsula in late summer. FEMS Microbiol. Lett. 365, 1-13. https://doi.org/10.1093/femsle/fny09 0 (2018).

17. Moreno-Pino, M. et al. Variation in coastal Antarctic microbial community composition at sub-mesoscale: spatial distance or environmental filtering? FEMS Microbiol. Ecol. 92, fiw088. https://doi.org/10.1093/femsec/fiw088 (2016).

18. Moon-van der Staay, S. Y., De Wachter, R. \& Vaulot, D. Oceanic 18S rDNA sequences from picoplankton reveal unsuspected eukaryotic diversity. Nature 409, 607-610. https://doi.org/10.1038/35054541 (2001).

19. Fuller, N. J. et al. Analysis of photosynthetic picoeukaryote diversity at open ocean sites in the Arabian Sea using a PCR biased towards marine algal plastids. Aquat. Microbial Ecol. 43, 79-93 (2006).

20. Shi, X. L., Lepère, C., Scanlan, D. J. \& Vaulot, D. Plastid 16 S rRNA gene diversity among eukaryotic picophytoplankton sorted by flow cytometry from the South Pacific Ocean. PLoS ONE 6, e18979 (2011).

21. Sieburth, J. M., Smetacek, V. \& Lenz, J. Pelagic ecosystem structure: heterotrophic compartments of the plankton and their relationship to plankton size fractions. Limnol. Oceanogr. 23, 1256-1263 (1978).

22. Marie, D., Shi, X. L., Rigaut-Jalabert, F. \& Vaulot, D. Use of flow cytometric sorting to better assess the diversity of small photosynthetic eukaryotes in the English Channel. FEMS Microbiol. Ecol. 72, 165-178 (2010).

23. Balzano, S., Marie, D., Gourvil, P. \& Vaulot, D. Composition of the summer photosynthetic pico and nanoplankton communities in the Beaufort Sea assessed by T-RFLP and sequences of the $18 \mathrm{~S}$ rRNA gene from flow cytometry sorted samples. ISME J. 6 , 1480-1498. https://doi.org/10.1038/ismej.2011.213 (2012).

24. Callahan, B. J. et al. DADA2: high-resolution sample inference from Illumina amplicon data. Nat. Methods 13, 581-583. https:// doi.org/10.1038/nmeth.3869 (2016).

25. Jeong, H. J. et al. Growth, feeding and ecological roles of the mixotrophic and heterotrophic dinoflagellates in marine planktonic food webs. Ocean Sci. J. 45, 65-91. https://doi.org/10.1007/s12601-010-0007-2 (2010).

26. Wilks, J. V. \& Armand, L. K. Diversity and taxonomic identification of Shionodiscus spp. in the Australian sector of the Subantarctic Zone. Diatom Res. 32, 295-307. https://doi.org/10.1080/0269249X.2017.1365015 (2017).

27. Moreno, C. M. et al. Examination of gene repertoires and physiological responses to iron and light limitation in Southern Ocean diatoms. Polar Biol. 41, 679-696. https://doi.org/10.1007/s00300-017-2228-7 (2018).

28. Balzano, S. et al. Morphological and genetic diversity of Beaufort Sea diatoms with high contributions from the Chaetoceros neogracilis species complex. J. Phycol. 53, 161-187. https://doi.org/10.1111/jpy.12489 (2017).

29. Worden, A. Z. et al. Global distribution of a wild alga revealed by targeted metagenomics. Curr. Biol. 22, R675-R677 (2012).

30. Balzano, S. et al. Diversity of cultured photosynthetic flagellates in the North East Pacific and Arctic Oceans in summer. Biogeosciences 9, 4553-4571. https://doi.org/10.5194/bg-9-4553-2012 (2012).

31. Kuwata, A. et al. Bolidophyceae, a sister picoplanktonic group of diatoms-a review. Front. Mar. Sci. 5, 370. https://doi.org/10.3389/ fmars.2018.00370 (2018).

32. Massana, R., del Campo, J., Sieracki, M. E., Audic, S. \& Logares, R. Exploring the uncultured microeukaryote majority in the oceans: reevaluation of ribogroups within stramenopiles. ISME J. 8, 854-866 (2014).

33. Tragin, M. \& Vaulot, D. Novel diversity within marine Mamiellophyceae (Chlorophyta) unveiled by metabarcoding. Sci. Rep. 9, 5190. https://doi.org/10.1038/s41598-019-41680-6 (2019).

34. van den Hoff, J., Bell, E. \& Whittock, L. Dimorphism in the Antarctic cryptophyte Geminigera cryophila (Cryptophyceae). J. Phycol. 56, 1028-1038. https://doi.org/10.1111/jpy.13004 (2020).

35. Needham, D. M. \& Fuhrman, J. A. Pronounced daily succession of phytoplankton, archaea and bacteria following a spring bloom. Nat. Microbiol. 1, 16005. https://doi.org/10.1038/nmicrobiol.2016.5 (2016).

36. Lin, Y., Gifford, S., Ducklow, H., Schofield, O. \& Cassar, N. Towards quantitative microbiome community profiling using internal standards. Appl. Environ. Microbiol. 85, 1-14 (2019).

37. van Leeuwe, M. A. et al. Annual patterns in phytoplankton phenology in Antarctic coastal waters explained by environmental drivers. Limnol. Oceanogr. 65, 1651-1668. https://doi.org/10.1002/lno.11477 (2020).

38. Wasilowska, A., Kopczynska, E. E. \& Rzepecki, M. Temporal and spatial variation of phytoplankton in Admiralty Bay, South Shetlands: the dynamics of summer blooms shown by pigment and light microscopy analysis. Polar Biol. 38, 1249-1265. https:// doi.org/10.1007/s00300-015-1691-2 (2015).

39. Rozema, P. D. et al. Summer microbial community composition governed by upper-ocean stratification and nutrient availability in northern Marguerite Bay, Antarctica. Deep Sea Res. Part II Top. Stud. Oceanogr. 139, 151-166. https://doi.org/10.1016/j. dsr2.2016.11.016 (2016).

40. Annett, A. L., Carson, D. S., Crosta, X., Clarke, A. \& Ganeshram, R. S. Seasonal progression of diatom assemblages in surface waters of Ryder Bay, Antarctica. Polar Biol. 33, 13-29. https://doi.org/10.1007/s00300-009-0681-7 (2010).

41. Garibotti, I. et al. Phytoplankton spatial distribution patterns along the western Antarctic Peninsula (Southern Ocean). Mar. Ecol. Prog. Ser. 261, 21-39. https://doi.org/10.3354/meps261021 (2003). 
42. de Lima, D. T. et al. Abiotic changes driving microphytoplankton functional diversity in Admiralty Bay, King George Island (Antarctica). Front. Mar. Sci. 6, 1-17. https://doi.org/10.3389/fmars.2019.00638 (2019).

43. Luria, C. M., Ducklow, H. W. \& Amaral-Zettler, L. A. Marine bacterial, archaeal and eukaryotic diversity and community structure on the continental shelf of the western Antarctic Peninsula. Aquat. Microbial Ecol. 73, 107-121. https://doi.org/10.3354/ame01703 (2014).

44. Luo, W. et al. Molecular diversity of microbial eukaryotes in sea water from Fildes Peninsula, King George Island, Antarctica. Polar Biol. 39, 605-616. https://doi.org/10.1007/s00300-015-1815-8 (2016).

45. Rozema, P. D. et al. Interannual variability in phytoplankton biomass and species composition in northern Marguerite Bay (West Antarctic Peninsula) is governed by both winter sea ice cover and summer stratification. Limnol. Oceanogr. 62, 235-252. https:// doi.org/10.1002/lno.10391 (2017).

46. Lee, S. H. et al. Large contribution of small phytoplankton at Marian Cove, King George Island, Antarctica, based on long-term monitoring from 1996 to 2008. Polar Biol. 38, 207-220. https://doi.org/10.1007/s00300-014-1579-6 (2015).

47. Kang, J. S., Kang, S. H., Kim, D. \& Kim, D. Y. Planktonic centric diatom Minidiscus chilensis dominated sediment trap material in eastern Bransfield Strait, Antarctica. Mar. Ecol. Prog. Ser. 255, 93-99 (2003).

48. Vaulot, D., Eikrem, W., Viprey, M. \& Moreau, H. The diversity of small eukaryotic phytoplankton $(\leq 3 \mu \mathrm{m})$ in marine ecosystems. FEMS Microbiol. Rev. 32, 795-820. https://doi.org/10.1111/j.1574-6976.2008.00121.x (2008).

49. Andersen, R. A., Saunders, G. W., Paskind, M. P. \& Sexton, J. Ultrastructure and 18S rRNA gene sequence for Pelagomonas calceolata gen. and sp. nov. and the description of a new algal class, the Pelagophyceae classis nov. J. Phycol. 29, 701-715 (1993).

50. Dìez, B., Pedrós-Alió, C. \& Massana, R. Study of genetic diversity of eukaryotic picoplankton in different oceanic regions by smallsubunit rRNA gene cloning and sequencing. Appl. Environ. Microbiol. 67, 2932-2941. https://doi.org/10.1128/AEM.67.7.29322941.2001 (2001).

51. Gérikas Ribeiro, C. et al. Culturable diversity of Arctic phytoplankton during pack ice melting. Elem. Sci. Anthropocene 8, 6. https ://doi.org/10.1525/elementa.401 (2020).

52. Sow, L. S. S., Trull, T. W. \& Bodrossy, L. Oceanographic fronts shape Phaeocystis assemblages: a high-resolution 18 S rRNA gene survey from the ice-edge to the equator of the South Pacific. Front. Microbiol. 11, 1847. https://doi.org/10.3389/fmicb.2020.01847 (2020).

53. Gaebler, S., Hayes, P. K. \& Medlin, L. K. Methods used to reveal genetic diversity in the colony-forming prymnesiophytes Phaeocystis antarctica, P. globosa and P. pouchetii-preliminary results. In Phaeocystis Major Link in the Biogeochemical Cycling of Climate-Relevant Elements (eds van Leeuwe, M. et al.) 330 (Springer Netherlands, Houten, 2007). https://doi.org/10.1007/978-1-4020-6214-8.

54. DiTullio, G. R. et al. Rapid and early export of Phaeocystis antarctica blooms in the Ross Sea, Antarctica. Nature 404, 595-598. https://doi.org/10.1038/35007061 (2000).

55. Arrigo, K. R. et al. Phytoplankton taxonomic variability in nutrient utilization and primary production in the Ross Sea. J. Geophys. Res. Oceans 105, 8827-8846. https://doi.org/10.1029/1998JC000289 (2000).

56. van Leeuwe, M. A. \& Stefels, J. Photosynthetic responses in Phaeocystis antarctica towards varying light and iron conditions. Biogeochemistry 83, 61-70. https://doi.org/10.1007/s10533-007-9083-5 (2007).

57. Gast, R. J., McKie-Krisberg, Z. M., Fay, S. A., Rose, J. M. \& Sanders, R. W. Antarctic mixotrophic protist abundances by microscopy and molecular methods. FEMS Microbiol. Ecol. 89, 388-401. https://doi.org/10.1111/1574-6941.12334 (2014).

58. Sekiguchi, H., Kawachi, M., Nakayama, T. \& Inouye, I. A taxonomic re-evaluation of the Pedinellales (Dictyochophyceae), based on morphological, behavioural and molecular data. Phycologia 42, 165-182. https://doi.org/10.2216/i0031-8884-42-2-165.1 (2003).

59. Li, Q., Edwards, K. F., Schvarcz, C. R., Selph, K. E. \& Steward, G. F. Plasticity in the grazing ecophysiology of Florenciella (Dichtyochophyceae), a mixotrophic nanoflagellate that consumes Prochlorococcus and other bacteria. Limnol. Oceanogr.. https://doi. org/10.1002/lno.11585 (2020).

60. Maruyama, S. \& Kim, E. A modern descendant of early green algal phagotrophs. Curr. Biol. 23, 1081-1084. https://doi.org/10.1016/j. cub.2013.04.063 (2013).

61. Darling, K. F. et al. Molecular evidence for genetic mixing of Arctic and Antarctic subpolar populations of planktonic foraminifers. Nature 405, 43-47. https://doi.org/10.1038/35011002 (2000).

62. Sul, W. J., Oliver, T. A., Ducklow, H. W., Amaral-Zettler, L. A. \& Sogin, M. L. Marine bacteria exhibit a bipolar distribution. Proc. Natl. Acad. Sci. USA 110, 2342-2347. https://doi.org/10.1073/pnas.1212424110 (2013).

63. Wolf, C., Kilias, E. \& Metfies, K. Protists in the polar regions: comparing occurrence in the Arctic and Southern oceans using pyrosequencing. Polar Res. 34, 23225. https://doi.org/10.3402/polar.v34.23225 (2015).

64. Lovejoy, C. \& Potvin, M. Microbial eukaryotic distribution in a dynamic Beaufort Sea and the Arctic Ocean. J. Plankton Res. 33 , 431-444. https://doi.org/10.1093/plankt/fbq124 (2011).

65. Delmont, T. O., Murat Eren, A., Vineis, J. H. \& Post, A. F. Genome reconstructions indicate the partitioning of ecological functions inside a phytoplankton bloom in the Amundsen Sea, Antarctica. Front. Microbiol. 6, 1-19. https://doi.org/10.3389/fmicb .2015.01090 (2015).

66. Simmons, M. P. et al. Intron invasions trace algal speciation and reveal nearly identical arctic and antarctic Micromonas populations. Mol. Biol. Evol. 32, 2219-2235. https://doi.org/10.1093/molbev/msv122 (2015).

67. Joli, N., Monier, A., Logares, R. \& Lovejoy, C. Seasonal patterns in Arctic prasinophytes and inferred ecology of Bathycoccus unveiled in an Arctic winter metagenome. ISME J. 6, 1372-1385. https://doi.org/10.1038/ismej.2017.7 (2017).

68. Benner, I., Irwin, A. J. \& Finkel, Z. Capacity of the common Arctic picoeukaryote Micromonas to adapt to a warming warming ocean. Limnol. Oceanogr. Lett. 5, 221-227 (2019).

69. Li, W. K., McLaughlin, F. A., Lovejoy, C. \& Carmack, E. C. Smallest algae thrive as the Arctic Ocean freshens. Science 326, 539. https://doi.org/10.1126/science.1179798 (2009).

70. Hoppe, C. J. M., Flintrop, C. M. \& Rost, B. The arctic picoeukaryote Micromonas pusilla benefits synergistically from warming and ocean acidification. Biogeosciences 15, 4353-4365. https://doi.org/10.5194/bg-15-4353-2018 (2018).

71. Vannier, T. et al. Survey of the green picoalga Bathycoccus genomes in the global ocean. Sci. Rep. 6, 37900. https://doi.org/10.1038/ srep37900 (2016).

72. Vaulot, D. et al. Metagenomes of the Picoalga Bathycoccus from the Chile coastal upwelling. PLoS ONE 7, e39648. https://doi. org/10.1371/journal.pone.0039648 (2012).

73. Kauko, H. M. et al. Algal colonization of young Arctic sea ice in spring. Front. Mar. Sci. 5, 1-20. https://doi.org/10.3389/fmars .2018.00199 (2018).

74. Schloss, I. R. et al. On the phytoplankton bloom in coastal waters of southern King George Island (Antarctica) in January 2010: an exceptional feature? Limnol. Oceanogr. 59, 195-210. https://doi.org/10.4319/lo.2014.59.1.0195 (2014).

75. Świło, M., Majewski, W., Minzoni, R. T. \& Anderson, J. B. Diatom assemblages from coastal settings of West Antarctica. Mar. Micropaleontol. 125, 95-109. https://doi.org/10.1016/j.marmicro.2016.04.001 (2016).

76. Pike, J. et al. Observations on the relationship between the Antarctic coastal diatoms Thalassiosira antarctica Comber and Porosira glacialis (Grunow) Jørgensen and sea ice concentrations during the late Quaternary. Mar. Micropaleontol. 73, 14-25. https://doi. org/10.1016/j.marmicro.2009.06.005 (2009).

77. Luddington, I. A., Lovejoy, C. \& Kaczmarska, I. Species-rich meta-communities of the diatom order Thalassiosirales in the Arctic and northern Atlantic Ocean. J. Plankton Res. 38, 781-797. https://doi.org/10.1093/plankt/fbw030 (2016). 
78. Hoppenrath, M. et al. Thalassiosira species (Bacillariophyceae, Thalassiosirales) in the North Sea at Helgoland (German Bight) and Sylt (North Frisian Wadden Sea) - A first approach to assessing diversity. Eur. J. Phycol. 42, 271-288. https://doi.org/10.1080/09670 260701352288 (2007).

79. Schoemann, V., Becquevort, S., Stefels, J., Rousseau, V. \& Lancelot, C. Phaeocystis blooms in the global ocean and their controlling mechanisms: a review. J. Sea Res. 53, 43-66. https://doi.org/10.1016/j.seares.2004.01.008 (2005).

80. Lange, M., Chen, Y. Q. \& Medlin, L. K. Molecular genetic delineation of Phaeocystis species (Prymnesiophyceae) using coding and non-coding regions of nuclear and plastid genomes. Eur. J. Phycol. 37, 77-92. https://doi.org/10.1017/S0967026201003481 (2002).

81. Medlin, L. K., Lange, M. \& Baumann, M. E. Genetic differentiation among three colony-forming species of Phaeocystis: further evidence for the phylogeny of the Prymnesiophyta. Phycologia 33, 199-212. https://doi.org/10.2216/i0031-8884-33-3-199.1 (1994).

82. Thompson, D. W. \& Solomon, S. Interpretation of recent Southern Hemisphere climate change. Science 296, 895-899. https://doi. org/10.1126/science.1069270 (2002).

83. Smith, R. C. \& Stammerjohn, S. E. Variations of surface air temperature and sea-ice extent in the western Antarctic Peninsula region. Ann. Glaciol. 33, 493-500. https://doi.org/10.3189/172756401781818662 (2001).

84. Hansen, M. O., Nielsen, T. G., Stedmon, C. A. \& Munk, P. Oceanographic regime shift during 1997 in Disko Bay, Western Greenland. Limnol. Oceanogr. 57, 634-644. https://doi.org/10.4319/lo.2012.57.2.0634 (2012).

85. Holm-Hansen, O., Lorenzen, C. J., Holmes, R. W. \& Strickland, J. D. H. Fluorometric determination of chlorophyll. ICES J. Mar. Sci. 30, 3-15. https://doi.org/10.1093/icesjms/30.1.3 (1965).

86. Marie, D., Rigaut-Jalabert, F. \& Vaulot, D. An improved protocol for flow cytometry analysis of phytoplankton cultures and natural samples. Cytometry 85, 962-968. https://doi.org/10.1002/cyto.a.22517 (2014).

87. Gérikas Ribeiro, C., Lopes dos Santos, A., Marie, D., Pereira Brandini, F. \& Vaulot, D. Small eukaryotic phytoplankton communities in tropical waters off Brazil are dominated by symbioses between Haptophyta and nitrogen-fixing cyanobacteria. ISME J. 12, 1360-1374. https://doi.org/10.1038/s41396-018-0050-z (2018).

88. Piredda, R. et al. Diversity and temporal patterns of planktonic protist assemblages at a Mediterranean Long Term Ecological Research site. FEMS Microbiol. Ecol. 93, fiw200. https://doi.org/10.1093/femsec/fiw200 (2017).

89. Lepère, C. et al. Whole Genome Amplification (WGA) of marine photosynthetic eukaryote populations. FEMS Microbiol. Ecol. 76, 516-523 (2011).

90. Martin, M. Cutadapt removes adapter sequences from high-throughput sequencing reads. EMBnet J. 17, 10-12. https://doi. org/10.14806/ej.17.1.200 (2011).

91. R Development Core Team. R: A Language and Environment for Statistical Computing. https://doi.org/10.1007/978-3-540-74686 -7 (2013).

92. Guillou, L. et al. The Protist Ribosomal Reference database $\left(\mathrm{PR}^{2}\right)$ : a catalog of unicellular eukaryote Small Sub-Unit rRNA sequences with curated taxonomy. Nucleic Acids Res. 41, D597-D604. https://doi.org/10.1093/nar/gks1160 (2013).

93. Decelle, J. et al. PhytoREF: a reference database of the plastidial 16S rRNA gene of photosynthetic eukaryotes with curated taxonomy. Mol. Ecol. Resour. 15, 1435-1445. https://doi.org/10.1111/1755-0998.12401 (2015).

94. Wickham, H., François, R., Henry, L. \& Müller, K. dplyr: A Grammar of Data Manipulation. R package version 1.0.2. (2020)

95. Wilkins, D. treemapify: Draw Treemaps in 'ggplot2'. R package version 2.5.3. (2019)

96. McMurdie, P. J. \& Holmes, S. phyloseq: an r package for reproducible interactive analysis and graphics of microbiome census data. PLoS ONE 8, 1-11. https://doi.org/10.1371/journal.pone.0061217 (2013).

97. Dixon, P. Vegan, a package of $\mathrm{r}$ functions for community ecology. J. Veg. Sci. 14, 927-930. https://doi.org/10.1111/j.1654-1103.2003. tb02228.x (2003).

98. Gehlenborg, N. UpSetR: A More Scalable Alternative to Venn and Euler Diagrams for Visualizing Intersecting Sets. R package version 1.4.0. (2019)

\section{Acknowledgements}

This work was funded by INACH RG_31-15, INACH RT_34-17 and FONDECYT No. 1190879 grants. Collaboration between Chile and France was funded through ECOS-CONICYT No. C16B02 and CNRS International Research Network "Diversity, Evolution and Biotechnology of Marine Algae" (GDRI No. 0803). Catherine Gérikas Ribeiro was supported by the FONDECYT Project No. 3190827. The authors thank Dr. Ernesto Molina for sampling during autumn and spring, as well the logistic support at the scientific station Professor Julio Escudero, INACH. Adriana Lopes dos Santos was supported by the Singapore Ministry of Education, Academic Research Fund Tier 1 (RG26/19). We thank the Roscoff ABIMS platform of the FR2424 (CNRS, Sorbonne Université) for bioinformatics resources.

\section{Author contributions}

N.T., R.D.I., A.L.S. and D.V. designed the study. M.M., R.D.I., A.L.S., D.V. and N.T. collected the samples. A.C. and D.M. performed the flow cytometry analysis. A.C. and G.P.P. performed the DNA extractions and PCR amplifications. M.M., R.D.I., A.L.S., R.D.I., C.G.R., D.V. and N.T. performed the data analysis and interpretation. N.T., R.D.I., A.L.S., C.G.R. and D.V. wrote the paper. All authors read and approved the final manuscript.

\section{Competing interests}

The authors declare no competing interests.

\section{Additional information}

Supplementary Information The online version contains supplementary material available at https://doi. org/10.1038/s41598-020-80568-8.

Correspondence and requests for materials should be addressed to N.T. or D.V.

Reprints and permissions information is available at www.nature.com/reprints.

Publisher's note Springer Nature remains neutral with regard to jurisdictional claims in published maps and institutional affiliations. 
(c) (i) Open Access This article is licensed under a Creative Commons Attribution 4.0 International cc) License, which permits use, sharing, adaptation, distribution and reproduction in any medium or format, as long as you give appropriate credit to the original author(s) and the source, provide a link to the Creative Commons licence, and indicate if changes were made. The images or other third party material in this article are included in the article's Creative Commons licence, unless indicated otherwise in a credit line to the material. If material is not included in the article's Creative Commons licence and your intended use is not permitted by statutory regulation or exceeds the permitted use, you will need to obtain permission directly from the copyright holder. To view a copy of this licence, visit http://creativecommons.org/licenses/by/4.0/.

(C) The Author(s) 2021 